\title{
Geological constraints on mesoscale coastal barrier behaviour
}

\author{
Andrew Cooper ${ }^{a, b,{ }^{*}}$ \\ Andrew Green ${ }^{b}$ \\ Carlos Loureiro ${ }^{\mathrm{a}, \mathrm{b}, \mathrm{c}}$
}

a Geography and Environmental Science, University of Ulster, Cromore Road, Coleraine BT52 1SA, Northern Ireland, UK

${ }^{b}$ Discipline of Geology, University of KwaZulu-Natal, Westville Campus, Private Bag X54001, Durban 4000, South Africa

${ }^{c}$ Centre for Marine and Environmental Research, Universidade do Algarve, Campus de Gambelas, Faro 8005-139, Portugal

* Corresponding author

Email: jag.cooper@ulster.ac.uk, greena1@ukzn.ac.za, loureiroc@ukzn.ac.za

Published in:

Global and Planetary Change

Volume 168, September 2018, Pages 15-34

DOI: 10.1016/j.gloplacha.2018.06.006

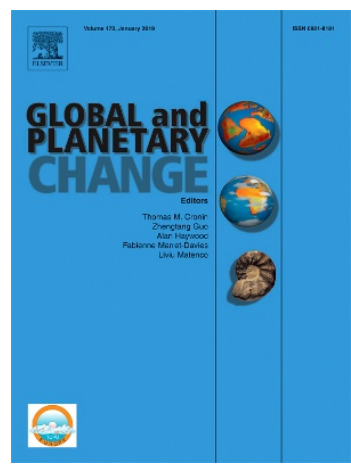

URL: https://www.sciencedirect.com/science/article/pii/S0921818118301851

Global and Planetary Change 168 (2018) 15-34

\begin{tabular}{cc} 
Contents lists available at ScienceDirect \\
GLSEVIER \\
\hline Elobal and Planetary Change \\
\hline
\end{tabular}

Invited review article

Geological constraints on mesoscale coastal barrier behaviour

J.A.G. Cooper ${ }^{\mathrm{a}, \mathrm{b}, *}$, A.N. Green ${ }^{\mathrm{b}}$, C. Loureiro ${ }^{\mathrm{a}, \mathrm{b}, \mathrm{c}}$

Geography and Environmental Science, University of Ulster, Cromore Road, Coleraine BT52 1SA, Northern Ireland, UK

Discipline of Geology, University of KwaZulu-Natal, Westville Campus, Private Bag X54001, Durban 4000, South Africa

"Centre for Marine and Environmental Research, Universidade do Algarve, Campus de Gambelas, Faro 8005-139, Portuga

A R T I CLE IN F O

A B S T R A C T

This post-print author's version of the manuscript is licensed under a Creative Commons AttributionNonCommercial-NoDerivatives 4.0 International License 
Highlights

Geological factors are significant controls on mesoscale barrier behaviour

Geological influences on barrier behaviour are identified and organized into a hierarchy of influences.

Initial barrier form significantly influences barrier behaviour and detailed measurement of barrier morphology is an essential prerequisite for any study.

Future research should focus on incorporating important geological influences into modelling efforts. The few sites with adequate data provide test cases.

Coastal management must acknowledge the qualitative nature of assessments of future change. 


\title{
Geological constraints on mesoscale coastal barrier behaviour
}

\author{
J.A.G. Cooper ${ }^{1,2}$, A.N. Green ${ }^{2}$, C. Loureiro ${ }^{1,2,3}$
}

1. Geography and Environmental Science, University of Ulster, Cromore Road, Coleraine, BT52 1SA, Northern Ireland, UK

2. Discipline of Geology, University of KwaZulu-Natal, Westville Campus, Private Bag X54001, Durban 4000, South Africa

3. Centre for Marine and Environmental Research, Universidade do Algarve, Campus de Gambelas, Faro, 8005-139, Portugal

\begin{abstract}
Barrier/lagoon systems occupy a significant part of the world's coast. They are diverse in size, morphology, geological and oceanographic setting, and morphodynamic behaviour. Understanding the behaviour of barriers at $10^{1}$ to $10^{2}$ year and $10^{1}$ to $10^{2}$ kilometre scales (mesoscale) is an important scientific and societal goal, not least because of the preponderance of intensive coastal development in a time of global climate change. Such understanding presents significant challenges. Challenges in describing mesoscale system behaviour relate largely to the incomplete evidence base of (i) morphological change in system components, (ii) dynamic and internal forcing factors (drivers) and (iii) geological constraints. These shortcomings curtail the development of baseline datasets against which to test models. Understanding observed changes and thereby predicting future behavioural patterns demands assumptions and simplifications regarding the linkages between initial state, dynamic drivers, system feedbacks and a multiplicity of geological constraints that are often location-specific.
\end{abstract}

The record of mesoscale change is improving with the acquisition of long-term morphological datasets. Advances in technology and chronological control mean that geological investigations can now provide decadal to century-scale temporal resolution of morphological change. In addition, exploratory modelling is improving understanding of the influence of various dynamic and geological factors. 
Straightforward linking of dynamic forcing and response is seldom able to account for observed mesoscale behaviour. Geological factors exert a significant or even dominant control on barrier behaviour at decadal to century timescales. Whereas these geological controls can be quantified to some extent by detailed investigations of contemporary barrier/lagoon morphology and constituent materials, underlying geology and topography and sediment supply, in all but a few locations, such data are absent. This sets an unavoidable constraint on efforts to quantitatively predict the future behaviour of barrier systems, which are strongly site-specific in terms of their geological setting and morphology. Geological controls exist in a network of interactions that individually and collectively influence mesoscale barrier behaviour. Dominant, first-order controls are:

- Basement slope;

- Basement irregularity and erodibility;

- External sediment supply;

- Orientation; and

- Shoreline lithification (beachrock and aeolianite)

An important intermediate level of geological control is exerted by shoreface morphology. Shorefaces are themselves influenced by underlying geological factors, but they are dynamic at longer timescales than barriers. Geological influences are in most cases unquantified and are usually disregarded when conceptualizing and modelling barrier evolution. Consideration of the geological influences is, however, essential in efforts to predict future behaviour at mesoscale (management) timescales.

Key Words: Barrier, sea-level change, sediment supply, antecedent topography, morphological modelling.

\section{Introduction}


Coastal barrier and barrier-island systems occupy a significant proportion of the world's coastline. They are chiefly composed of sand, with a significant minority of gravel-dominated barriers concentrated in formerly glaciated areas (Orford et al., 1991). Barrier islands occur on about $10 \%$ of the open ocean coast (Stutz and Pilkey, 2011), and, combined with mainland-attached examples, barriers make up about $15 \%$ of the world's ocean shoreline (Davies, 1980). Barriers are also widespread in lowenergy, fetch-limited settings of lagoons and bays (Cooper et al., 2007; Pilkey et al., 2009).

In morphodynamic terms, barriers are dynamic, unconsolidated sedimentary systems that respond to various drivers. These drivers may be short-term (e.g. low magnitude/high frequency or modal wave and tide processes), episodic (e.g. wave energy and water level changes during storms (Stone et al., 2004; Houser et al., 2008)), medium term (e.g. the cumulative effect of modal wave and tides; climate oscillations), or longer term (e.g. sea-level change, storminess patterns). The influence of these drivers, however, is mediated by non-dynamic (geological) variables such as the nature of the underlying geology and topography, sediment supply, and the morphology of the barrier/lagoon system itself. These geological controls are difficult to quantify and are often overlooked, ignored or grossly simplified in approaches to understanding or predicting barrier behaviour.

Aside from the importance of barrier-related sediments in the geological record (where they often form petroleum reservoirs), understanding barrier coast behaviour at timescales of decades to centuries is a pressing societal need because of the proximity of human development either on, or adjacent to, barrier systems. In some instances, this development takes advantage of aspects of barrier geomorphology (e.g. navigation through tidal inlets) or is based on proximity to the beach (Pilkey and Cooper, 2014). In many instances, barriers are so intensively human-developed that they are in effect coupled human-natural systems (Lazarus et al. 2015). Barriers, particularly those with extensive dunes, offer a degree of protection against extreme events (Houser et al., 2008), and they respond to changes in dynamic forcing by altering their morphology or material composition. 
Understanding decadal/centennial (mesoscale) barrier-lagoon behaviour is a complex 3-D problem in which dynamic factors (their net effect over decadal to century timescales) operate on a changing horizontal plane (sea-level) on materials of a given type within a particular geological framework. "Longer-term behaviour (years to decades) of the shoreline is the result of hydrodynamic and morphodynamic processes acting over multiple stormy and intervening calm periods during which the advanced or retreated state of the shoreline may be increasingly influenced by sediment supply and geology" (Hapke et al., 2016 p 42).

While the role of geological factors has long been recognized in long-term (millennial/stratigraphic-level) studies (Belknap and Kraft, 1985; Riggs et al., 1995), only comparatively recently has the importance of this influence been appreciated in mesoscale studies. In many mesoscale studies, incomplete historical records of morphological change taken in conjunction with more complete records of some (but not all) dynamic drivers (e.g. Elias and van der Spek, 2006; Styles et al., 2016) often identify certain morphodynamic relationships and feedbacks. In almost all cases, however, the geological parameters (underlying geology/geomorphology, sediment nature and supply) are unknown and are either unacknowledged, deliberately ignored or assumed to be unimportant. Yet, Hapke et al. $(2016$, p.43) contend that '... there are separable patterns of shoreline behaviour that represent response to oceanographic forcing as well as patterns that are not explained by this forcing. ' and Weymer et al. $(2015$, p.12) maintain that “..., an assessment of antecedent geology (i.e., geologic framework) is critical for coastal management and risk assessment ...". Such assessments of geological constraints are, however, largely absent in many modelling studies and predictions of future barrier behaviour.

Focusing particularly on the geological influences on mesoscale barrier behaviour, this review begins with a brief description of the essential system components and the diversity in barrier morphology. It briefly outlines current conceptual mesoscale behavioural models. Three main modes of enquiry into mesoscale barrier behaviour (historical, geological and modelling) are described and recent developments related to the understanding of geological controls are reviewed. The influences of these geological factors are discussed individually and collectively and their relevance for scientific understanding of barrier behaviour and for coastal management are outlined. 


\section{Common attributes and spatial variability in barrier-lagoon systems}

Many accounts of individual barriers and barrier systems exist and several syntheses have been produced (e.g. Davis, 1994; Leatherman, 1979; Oertel, 1985; Pilkey, 2003; McBride et al., 2013). The transgressive barrier island system diagram of Reinson (1992) is one of the most frequently reproduced and it includes the six main components of an idealized barrier/lagoon system, i.e. mainland; backbarrier lagoon; inlet and inlet deltas; barrier island; barrier platform; and shoreface (Oertel, 1985).

Facies models (Fig. 1) are useful in geological investigations, enabling local variability to be discarded and identifying the key geological constituents to aid in identification of modern and ancient barrier island systems. Despite the generic attributes of the barrier island facies model, individual or regional groups of barrierlagoon systems (e.g. McBride et al., 1995; Pilkey et al. 1989) show considerable morphological diversity (Fig. 2). Although such variability is regarded as "noise" from a facies model perspective, it introduces and/or results from variations in dynamics, and geological context that are fundamentally important in terms of how a given barrier/lagoon system functions at decadal to centennial timescales. A barrier whose crest is much higher than the highest wave run-up, for example, will preclude overwash, a process that is of crucial importance in the mesoscale behaviour of many other barrier systems (Leatherman, 1983).

Contemporary barrier-lagoon systems exhibit great morphological diversity that results from large scale climatic, oceanographic and geological influences (Fig. 2). They range in size from the massive Patos/Mirim Lagoon system of southern Brazil with its $600 \mathrm{~km}$-long barrier (Dillenberg and Hesp, 2009) and the $300 \mathrm{~km}-$ long Outer Banks barrier island chain off NC (Zaremba et al., 2016)) to the numerous small barriers (often $<100 \mathrm{~m}$ long) that characterise the rocky coasts of South Africa (Cooper, 2001), eastern Australia (Roy et al., 2001; Sloss et al., 2006) and New England (Duffy et al., 1989) for hundreds of kilometres. Barriers exhibit great diversity in height and width and adjacent lagoon dimensions (Fig 2F). They also vary in composition (gravel/sand), orientation and exposure to wave and tidal processes and occurrence of various extreme wave events (storms, hurricanes, 
tsunamis). Orford et al. (1995) consider a primary distinction in terms of historical barrier behaviour to be between drift- and swash-aligned barriers, a variable that combines coastal orientation (often dictated by antecedent geology) with wave climate.

Large-scale distinctions in barrier/lagoon geomorphology can also be made according to the specific coastal setting, with distinctive barrier-lagoon systems in deltaic (Anthony and Blivi, 1999; Stutz and Pilkey 2002), coastal plain (Pilkey, 2003) and rock-bounded settings (Cooper et al., 2012), for example. Climate is a further control, particularly with regard to the backbarrier environment. Arid lagoons in the Persian Gulf (Evans et al., 1973), for example, are in striking contrast to saltmarsh-dominated temperate lagoons, or mangrove-fringed tropical lagoons. Climatic setting also influences barrier dynamics and exposure to storm activity.

Some barrier systems (e.g. Outer Banks, NC, Frisian Islands, Netherlands) have multiple semi-permanent inlets, while others (including very large systems like Patos Lagoon, Brazil and St Lucia Lagoon, South Africa) have single inlets. Barriers in arid or episodic rainfall regions often have ephemeral inlets (McSweeney et al., 2017). Most barriers are sandy, but gravel-dominated systems are particularly common in (but are not confined to) formerly glaciated environments (Carter et al., 1984; Orford et al. 1991; Kirk and Lauder, 2000).

The initial morphology of a barrier system is a key determinant of its mesoscale behaviour. The initial form sets limits on the processes that occur (e.g. overwash, dune building, longshore drift, inlet-associated processes) and influences their magnitude and relative importance. The morphological variation outlined above demonstrates that, beyond the generalizations of the facies model, barrier systems are likely to be strongly site-specific in terms of their mesoscale behaviour. This aspect of geological inheritance is discussed further below.

\section{Barrier behaviour}

Barriers exhibit a range of generalized behaviours essentially involving sediment transfers along- and/or cross-shore, that result in morphological change. These are 
most commonly envisaged as simplified conceptual 2- or 3-D models and are outlined below.

\subsection{Profile models}

Conceptual 2-D profile responses of barriers fall broadly into four behavioural categories: rollover; erosion; overstepping; and aggradation/progradation (Fig. 3). In the rollover model, mesoscale barrier behaviour is dominated by overwashing during storms, such that the sediment volume is essentially maintained and the barrier migrates landward (Godfrey and Godfrey, 1973; Hosier and Cleary, 1977; Carter and Orford, 1981, Leatherman, 1983). The rollover response has been widely observed and reported. The rate of migration has been linked to (i) frequency of overwashing storms (Dolan and Godfrey, 1973; Schwartz, 1975; Byrnes and Gingerich, 1987); (ii) barrier volume (Forbes et al., 1991; Priestas and Fagherazzi, 2010); (iii) the gradient of the surface over which the barrier is migrating (Wolinsky and Murray, 2009); and (iv) the rate of sea-level rise. Very fast rates of barrier rollover $(30 \mathrm{~m} / \mathrm{year})$ sustained for several decades were attributed to the small volume of sediment in the low energy barriers in Chesapeake Bay (Cooper, 2013). On low energy barriers the influence of underlying substrate type is particularly evident - periods of barrier stability occur while fronting marsh deposits are eroded, whereupon barrier migration resumes (Fig. 4). High and/or very wide barriers, in contrast, do not overwash and do not exhibit rollover (e.g. Benallack et al., 2016). Barrier migration is also likely to be affected by the depth and volume of the lagoon: there may be insufficient sediment volume in a migrating barrier to fill the backing lagoon in which case the barrier will lose its integrity and will break down.

The erosional response (Fig. 3B) involves the seaward loss of sediment from a barrier during transgression. The Bruun Rule, the best-known parameterization of the erosional response (Carter, 1988) and various profile models based on shoreface retreat, involve simultaneous retreat of the dune, beach, surf zone and shoreface at the same rate, so as to maintain the nearshore profile. The concept of shoreface retreat has assumed a position of pre-eminence in mesoscale barrier evolution and forms the central concept in several investigative models (see below). Aside from various other flaws in the concept and formulation of the Bruun Rule and its derivatives (Cooper 
and Pilkey 2004a; Pilkey and Cooper, 2004), the retreat of shorefaces and barriers at the same rate is not widely observed in nature. Rather, shorefaces often retreat at slower rates than adjacent barriers and as they do so they exhibit varying behaviour (Swift et al., 1985). Erosion is the dominant profile response on high barriers that preclude overwash. High dune-topped barriers in southwestern Ireland, for example, show fluctuating shoreline positions due to off-shore and onshore sediment transfers that appear to be linked to storm frequency (Orford et al., 1999). Following a storm surge in 2008 , one of these barrier shorelines retreated at ca. $25 \mathrm{~m} /$ year, losing sand offshore (Devoy, 2015).

Overstepping (McMaster and Garrison, 1967; Sanders and Kumar, 1975; Rampino and Sanders, 1981, 1982) involves a barrier being drowned in situ, leaving much of its sediment and associated back-barrier sediments on the seabed (Fig 3C). Overstepping requires the reaction time of a barrier to be slow and/or the rate of sealevel rise to be fast, a concept that was initially argued to be unsupportable due to a disconnect between instantaneous responses to storms and the long-term response to sea-level rise (Swift and Moslow, 1982). The process has, however, since been documented at several locations (e.g. Forbes et al., 1991) and been linked to centuryscale periods of rapid sea-level rise (meltwater pulses) (Green et al., 2014, Cooper et al., 2016). Often the former barrier is eroded by subsequent shoreface ravinement (Rieu et al., 2005, Storms et al., 2008, Hijma et al., 2010), leaving only the backbarrier sediments, but in other instances (Green et al., 2014; Cooper et al., 2016) the barrier structure itself is preserved. These two scenarios have been termed Sediment Surplus Overstepping (minimal wave reworking and almost complete barrier preservation) and Sediment Deficit Overstepping (barrier moves landward in a sporadic, discontinuous fashion with little possibility of preservation) (Mellet et al., 2012). Favourable conditions for barrier preservation during overstepping include early cementation (e.g. Gardner et al., 2005, 2007; Green et al., 2013a, 2014, 2018), long relaxation times, as in gravel and boulder barriers (e.g. Forbes et al., 1991; Hartstein and Dickinson, 2000), an increase in back-barrier accommodation (linked to a low topographic gradient) (Storms et al. 2008), large sediment volume in the barrier (Orford et al., 1995) and low wave energy (Cooper et al., 2016). 
Under conditions of high sediment supply, barrier progradation or aggradation can occur during both falling and rising sea levels (Fig 3D). This can result in development of beachridge plains where a barrier steps seaward through welding of additional sediment (e.g. Green et al., 2013b; Hein et al., 2016), and/or development of high dunes when aeolian reworking of excess sediment is dominant (e.g. Dillenberg et al., 2004). Many sediment-rich barriers exhibit combinations of both aeolian and wave deposits (e.g. Hein et al., 2014).

\subsection{Planform Models}

2-D planform models are particularly well developed for gravel-dominated barriers but less so for sandy barriers. Working essentially in the mesoscale, Carter et al. (1987) presented a conceptual model for gravel barrier planform evolution related to interactions between sediment supply, antecedent topography and sea-level change. A variety of behavioural modes were identified that involve barrier elongation, stretching, cannibalization, breaching and breakdown (Fig. 5). The behaviour was linked to variations in sediment supply, rates of longshore and/or cross-shore sediment transport and sea-level rise. Similar modes of planform behaviour were noted in fetch-limited sand barriers in Chesapeake Bay (Fig. 6) where small island volume causes rapid barrier evolution. The specific role of sea-level rise could be identified by comparing single ridge gravel barriers in swash-aligned settings with varying decadal sea-level rise history (Orford et al., 1995). This demonstrated a clear link between rates of barrier migration and rates of sea-level rise, but even so, the potential influence of the barrier volume (inertia) was acknowledged.

On open ocean sandy barriers dynamic processes lead to periodic opening and closure of inlets, inlet and tidal delta migration, spit progradation, development of recurves and deposition of washover fans that change barrier island planforms. The specifics of their impacts on sandy barrier planform have, however, received less attention than their gravel counterparts. Hayes (1979) identified apparently genetic broadscale links between dynamics (tidal range and wave energy) and barrier planform. The global applicability of this observation has, however, recently been challenged by Mulhern et al. (2017) who found no systematic variation in shape in a global analysis of barrier planform morphometry. Attempting to codify mesoscale planform changes and link 
them to dynamic drivers, McBride et al. (1995) identified several types of planform behaviour on the ocean and bay sides of barriers in the Gulf of Mexico. These were divided into simple and complex behaviours (Fig. 7) that involved (1) lateral (alongshore) movement, (2) advance (cross-shore), (3) dynamic equilibrium, (4) retreat (cross-shore). In combination, these produced more complex behaviours involving (5) in-place narrowing, (6) landward rollover, (7) breakup, and (8) rotational instability. The various behavioural modes were conceptually and loosely linked to variations in rates of sea-level rise and sediment supply. An ideal example of the processes involved is provided at the mesoscale by Shanks Island, a fetchlimited barrier island chain in Chesapeake Bay (Cooper, 2013). Here (Fig.8) an initial barrier chain with several inlets experiences landward migration and lateral extension (1994-2006) followed by island widening and flattening (2006-2011) and near-total breakdown by 2013 .

\subsection{3-D barrier-lagoon models}

The profile and planform models are acknowledged as simplifications and it has long been known that sedimentary and dynamic relationships exist between the various elements of the barrier-lagoon system (e.g. back-barrier/marsh, tidal prism-tidal inlet, barrier island/tidal delta parts of the system).

In a regional appraisal of mesoscale barrier evolution in Louisiana, McBride and Byrnes (1997) recognized that barriers exhibited changes on both bay and ocean shorelines. They identified 7 'geomorphic response types' (lateral movement, retreat, breakup, advance, landward rollover, rotational instability and dynamic equilibrium). The three-dimensional nature of behaviour was illustrated in examples where growth of one barrier took place at the expense of downdrift barriers that retreated, and others where barrier narrowing was matched by sediment accumulation on the adjacent seabed. Aside from the contemporary morphodynamic linkages that influence this spatially variable barrier behaviour as sediment movement in one location influences adjacent areas, direct geological influences (e.g. subsurface relict delta lobes) were occasionally evident. 
FitzGerald et al. (2006; 2008; 2018) presented a conceptual 3D barrier-lagoon behavioural model that links backbarrier intertidal and supratidal marshes, tidal inlets and barrier evolution during rising sea level (Fig 9). In this model, rising sea level drowns marshes and increases the tidal prism. In response, the tidal inlets and ebb deltas enlarge at the expense of barrier island sand volume. Continued growth of the tidal prism under rising sea-level further enlarges the inlets and ebb deltas, to the point that insufficient sediment remains to maintain intervening barriers, at which point the barrier disintegrates and the open ocean shoreline 'jumps' to the former back-barrier shoreline, a mechanism termed 'runaway transgression' in this model. The application of this model to specific locations requires the quantification of barrier and ebb delta volumes, as well as the nature of the stratigraphy of the barriers. As noted by FitzGerald et al. (2018, p 47) “...this is not an easy task because of the large range in the size and sand volume of barriers throughout the world and the fact that barrier lithosomes vary considerably along their length due to changes in width, elevation, and depth.”

\subsection{Discussion: Conceptual barrier behaviour models}

Conceptual models of barrier behaviour have existed for several decades. Based on field observations and historical trends, they provide a description of several potential behavioural modes. Over time, however, it has become clear that these models are very much simplifications that incompletely describe actual mesoscale behaviour. Recent research has shown, however, that there are geological constraints on which behavioural mode is applicable in a given place and time. Overstepping, for example appears to be promoted by an increase in back-barrier accommodation (linked to a low topographic gradient) (Storms et al. 2008).

The factors that favour one response over another include: (i) dynamic factors such as wave energy and the rate of sea-level rise; (ii) morphological feedbacks between for example, tidal prism and delta volume; but also (iii) geological factors such as the accommodation space, coastal morphology being transgressed, barrier volume, sediment supply/texture and lithification. In addition, at any given locality factors absent in the conceptual models may be important; aeolian transport and dune 
building which is a dominant process on some barriers, does not feature in generic barrier models.

The assumptions inherent in some 2-D profile models in particular are not universally valid. Critical to both rollover and erosion models, for example, is the assumption that the shoreface migrates at similar rates to the barrier. It is, however, known that the shoreface exhibits morphological change at longer timescales than adjacent barriers (Swift et al., 1985). This is, however, spatially variable at the mesoscale. In some locations shoreface retreat does occur at rates comparable to adjacent barrier shoreline retreat (e.g. 5-15 m/yr on barrier island arcs on abandoned Mississippi delta lobes; Penland et al., 1985), but in many others (e.g. North Carolina, Riggs et al., 1995) the process of shoreface retreat is much slower than the adjacent barrier. In some instances, (e.g. German Frisian barrier islands, Flemming and Davis, 1994; Fire Island, NY, Kumar and Sanders, 1975) shoreface retreat does not accompany barrier migration. Instead barriers detach from the shoreface, leaving it drowned, while the surf zone and barrier migrate rapidly landward. The barrier may then form a new shoreface via erosion of underlying strata at its new stabilization point. The former shoreface may remain drowned, or as in the case of the Holland coast (Beets and van der Spek, 2000; Hijma et al., 2010), it may continue to migrate slowly landwards eventually 'catching up' with the surfzone and beach system when the latter stabilizes. The observational evidence therefore points to spatially variable relationships between shoreface and barrier behaviour, (Figure 10) the reasons for which have not been investigated but likely include variations in geological controls (sediment supply, underlying geology) as well as dynamic factors (rate of sea-level rise and wave climate).

\section{The record of decadal and century scale barrier evolution}

A fundamental prerequisite in understanding decadal to century-scale barrier evolution is observational data of changes in morphology and data on related dynamic variables. These can then be compared to seek relationships between behaviour and process and used to test models. Approaches involve historical records and geological investigations either individually or in combination. The nature and availability of data, and particularly their poor temporal spacing has often hampered 
the description of mesoscale barrier behaviour. Recent technological advances, however, are improving the situation.

\subsection{Historical records.}

"Changes in shoreline position tend to synthesize the net effect of coastal variables, thereby providing valuable insight regarding the geomorphic response of a coastal system”. (McBride et al., 1995, p.146)

The traditional approach to mesoscale barrier change involves analysis of historical data. Analysis of historical records (e.g. maps, nautical charts, air photos, satellite imagery) and repeat field surveys (e.g. of barrier profiles or shoreline position), are standard approaches. List et al. (1997) discuss the methods employed for historical bathymetric data collection, cartographic production, and seafloor change analysis. Often these records pertain to one or a few proxies of barrier position or morphology (high water mark, dune edge, etc) and, contrary to the assertion of McBride et al. (1995) above, each of the myriad of geoindicators records different aspects of coastal behaviour (Carapuço et al. 2016). The temporal record of morphological change is, however, always incomplete and it is necessary to rely on partial records of change and of potential drivers (sea-level change, climate forcing).

The short length of the historical record also impedes efforts to describe mesoscale barrier behaviour. Several European datasets (e.g. Ballarini et al., 2003; Villalobos et al., 2009; Fontolan et al., 2012; Poirier et al., 2017) span several hundred years but these comprise irregular and widely-spaced observations of variable accuracy. In the United States records seldom extend to more than 150 years (e.g. Morton, 2007).

The situation regarding the paucity of data is changing with time as more long-term data sets are compiled. In addition, technological advances (e.g. Light Detection and Ranging (LiDAR), multibeam bathymetry) now permit rapid, large-scale, 3-D repeat surveys to be undertaken (e.g. Raji et al., 2011). The utility of high-resolution LiDAR topographic mapping has been demonstrated in the understanding and storm impacts on barriers (Sallenger et al., 2001; Houser, 2013) and the detailed tracking of barrier 
topographic change over decades (White and Wang, 2003; Brock and Purkis, 2009; Lentz et al., 2013).

Historical records of sea-level change and dynamic drivers (wind, waves) are an essential element in attempts to understand observed morphological change. In most cases these records are site-specific and, except for a few long-term records, limited to a few decades. Measured wave records are especially short. The situation is changing with the widening network of operational wave buoys and the advent of global hindcast wind and wave models that demonstrate strong ability to simulate actual wave conditions for several decades past. The Global Ocean wave reanalysis (Reguero et al., 2012) extends back to 1948, for example, while the CERA-20C reanalysis (Buizza et. al., 2018) covers the entire $20^{\text {th }}$ century.

\subsection{Geological field investigations.}

Although traditionally viewed as millennial scale investigations at best, advances in technology in data acquisition and chronological control mean that many geological investigations of barrier/lagoon systems can achieve century to decadal temporal resolution (e.g. Fruergaard et al., 2015; Benallack et al., 2016; Costas et al., 2016). This is useful in understanding barrier behaviour because a much bigger range of sealevel change and environmental conditions was experienced over the Holocene than can be identified by historical investigations on modern coasts. The following examples illustrate the potential of evolving geological techniques to achieve mesoscale resolution.

In the St Lucia lagoon of South Africa, Benallack et al. (2016) and Humphries et al. (2016) used long cores and high-resolution AMS dating, together with high-resolution seismic profiling to identify centennial scale responses of the back-barrier to sea-level forcing and climate oscillations. Using micropalaeontological proxies from the cores, Gomes et al. (2017) documented periods of barrier growth, sealing and storm-wave inundation at the sub-millennial scale. These findings correlated and confirmed findings of Porat and Botha (2009) that employed ground penetrating radar (GPR) and OSL dating to understand the history of the dune barrier. 
Zaremba et al. (2016) similarly used ultra-high frequency seismic reflection profiling, vibrocores and AMS dating to study the Holocene evolution of Pamlico Sound at centennial timescales. This was supported by adjoining GPR profiles and cores from the barrier islands (Mallinson et al., 2010). These studies enabled a century-scale analysis of barrier changes associated with the Medieval Climate Anomaly, followed by inlet closures and barrier consolidation since $500 \mathrm{cal} \mathrm{BP}$.

Clarke et al. (2014) used grain size analysis from a small back-barrier system in California to infer decadal cycles of barrier-inlet breaching and closure. These were further linked to climatic drivers at the decadal scale using a combination of wavelet analyses coupled to very-high resolution dating using anthropogenic radionuclides.

Improvements in dating techniques (Van Heteren et al., 2000; Preusser and Schreurs, 2011) mean that changes in geological studies can now be documented at century scale that provide insights into shoreline translation rates associated with barrier overstepping, for example, that are not observable in historic records of barrier change. Since the inception of OSL dating of clastic sediments in 1985 (Rink and Lopez, 2010) several studies have employed the technique to establish decadal to century scale records of barrier behaviour. Studies on prograded barriers in particular have been able to assess the frequency and impact of extreme wave events on overall progradation rates (Rink and Lopez, 2010; Tamura 2012) and to link historic change to millennial scale evolution (Oliver et al., 2017). Mellett et al. (2011) resolved the timing of formation and subsequent overstepping of a gravel barrier in the English Channel using high-resolution seismic profiling and coring and were able to resolve formation and breaching dates at century timescales. High-resolution bathymetric and seismic studies of the drowned barrier systems of the SE African shelf revealed extensive barrier and back-barrier systems that were preserved by an early Holocene meltwater pulse (Green et al., 2013a; Salzmann et al., 2013; Green et al., 2014). Pretorius et al. (2016) used ultra-high resolution seismic data and cores from the back barrier of one of these systems to unravel stepped changes in Holocene sea level. Alternating rollover and overstepping of the barrier was attributed to centennial-scale alterations in sea level. De Falco et al. (2015) documented a drowned barrier and back barrier system in the northern Adriatic. They concluded that barrier evolved 
over a time period of $1 \mathrm{ka}$ and the time between formation and drowning of barriers was in the centennial timescale.

In addition to the mesoscale record of barrier change that can be deduced from geological studies, a range of traditional and emerging technologies enables the framework geology of barrier islands and their surroundings to be investigated (Weymer et al. 2015).

\section{Statistical and investigative modelling approaches}

Modelling approaches to barrier-lagoon behaviour at the scales of decades to centuries have traditionally aimed at understanding process-response relationships. As discussed above, those models can only be tested against incomplete records of dynamic forcing, partial records of morphological response and near absence of data on underlying geological control. A variety of approaches have been applied over the past two decades, including statistical, morphological-behaviour and process-based models, to investigate the range and direction of behaviour or the relationship between various process-response variables. Nonetheless, investigative models can be used to better understand barrier behaviour.

Statistical or data-driven approaches to large-scale coastal behaviour of barrier systems are typically based on the analysis of morphological datasets collected during lengthy and coherent monitoring programs. The statistical techniques employed rely solely on the mathematical analysis of records of morphological change, without invoking detailed treatment of the physical processes (Reeve and Karaunarathan, 2009). A wide range, from simple to advanced statistical techniques, have been applied to coastal morphological datasets (Kroon et al., 2008) to understand mesoscale behaviour. Empirical orthogonal function (EOF) decomposition is perhaps the most commonly used technique to identify decadal patterns of barrier behaviour (Wijnberg and Terwindt, 1995; Hapke et al., 2016). While EOF and other statistical techniques have proved useful for understanding past behaviour (Kroon et al., 2008), there is limited application of data-driven models to forecasting coastal change (Reeve et al., 2016). Recently, however, probabilistic data-driven approaches based on Bayesian Networks (BN) have been used to predict long-term shoreline change on 
barrier islands, given their ability to assimilate large observational datasets of coastal change and integrate them with boundary and forcing variables. Plant et al. (2016), building on the work of Gutierrez et al. $(2011,2015)$ developed a long-term predictive model for dune-height, shoreline change rate, and shoreline position on barrier islands, demonstrating that inclusion of a dune-height constraint improved the shoreline-change prediction.

Morphological-behaviour models, also termed exploratory (Murray, 2003) or reduced complexity models (Murray, 2007), aimed at simulating large-scale coastal morphological behaviour and stratigraphic evolution of barrier systems in response to changes in sea-level and sediment volume have proliferated since the 1990s (FitzGerald et al., 2008). From the outset, the morphological-behaviour modelling approaches to barriers varied significantly, ranging from numerical implementation of empirical geometric relationships, to parameterized mathematical-physics models (de Vriend, 1991), and adopting different methods for aggregating coastal features and processes into sub-systems (Cowell et al., 2003). Without necessarily implying increasing degrees of model complexity, Lorenzo-Trueba and Ashton (2014) subdivided barrier morphological-behaviour evolution modelling approaches as morphokinematic, relaxed morphokinematic and morphodynamic (Fig. 11). Common to all approaches is sediment mass conservation (Wolinsky and Murray, 2009) and barrier schematization based on an idealized cross-shore configuration (discretized into relevant spatial components that normally include the shoreface, barrier and lagoon).

Morphokinematic models simulate long-term barrier evolution as simple translation driven by sea-level change, disregarding the processes that lead to morphological change (e.g. overwash), while considering geometrical shapes based on equilibrium concepts (Lorenzo-Trueba and Ashton, 2014). As such, morphokinematic models of barrier evolution tend to rely on assumptions such as the generalized Bruun rule of Dean and Maurmeyer (1983), where the entire barrier system maintains its form while migrating landward with sea-level rise (Fitzgerald et al., 2008; Lorenzo-Trueba and Ashton, 2014). The Shoreface Translation Model (STM) of Cowell et al. (1992, 1995) encapsulates this approach, with morphological evolutionary modes ranging from barrier translation (i.e. roll over) to encroachment, determined fundamentally by 
the steepness of the pre-existing substrate. The role of geological inheritance in barrier evolution is partly incorporated in STM via the substrate slope, although the substrate can also be freely reworked given its parameterization as unconsolidated sediment (Cowell et al., 1995). The assumptions regarding shoreface profile shape in such approaches have been identified as a fundamental weakness (Cooper and Pilkey, 2004a; Pilkey and Cooper, 2006).

Building on the morphological-behaviour concepts and sediment conservation rules proposed by Cowell et al. (1995) in STM, Stolper et al. (2005) developed the Geomorphic Model of Barrier, Estuarine, and Shoreface Translations (GEOMBEST). By handling the substrate as distinct (user defined) stratigraphic units with variable sediment composition and erodibility, as well as incorporating a depth-dependent response rate, GEOMBEST implementation allows relaxation of the assumption of equilibrium profile configuration and can simulate the influence of complex geological inheritance in barrier morphological evolution (Stolper et al. 2005; Moore et al., 2010). Disequilibrium becomes a fundamental aspect of this modelling approach (FitzGerald et al., 2008), leading to its classification as relaxed morphokinematics (Lorenzo-Trueba and Ashton, 2014). Given GEOMBEST's flexible approach and implementation, it has been increasingly used to investigate the coupled long-term evolution of barrier-lagoon systems, providing new insights into barrier disintegration (Moore et al., 2014), interactions between backbarrier deposition, substrate slope and underlying stratigraphy (Brenner et al., 2015), and the influence of backbarrier marshes on barrier island evolution (Walters et al., 2014).

Morphological-behaviour models that focus on sediment fluxes, explicitly simulating the principal erosional and depositional processes and/or feedbacks that drive longterm barrier island evolution are defined as morphodynamic (Lorenzo-Trueba and Ashton, 2014). Morphodynamic models vary in complexity and time scales. On the longer, geological scale, the stratigraphic process-response BARSIM model (Storms et al., 2002; Storms, 2003) considers barrier evolution as event-driven, simulating different depositional patterns for storms and intervening fair-weather conditions. Also at the millennial-scale, Masetti et al. (2008) proposed the Barrier Island Translation (BIT) morphodynamic model which uses simplified equations to simulate barrier evolution due to wave-driven sediment diffusion in the inner shelf and 
sediment reworking on the shoreface, sediment overwash on the barrier during energetic events and lagoonal deposition in the backbarrier. More recently, LorenzoTrueba and Ashton (2014) introduced a morphodynamic morphological-behaviour model that focuses separately on the active shoreface (treated as a single linear unit) and the barrier-backbarrier domain. The centennial scale evolution of the barrier system is driven by shoreface fluxes, passive flooding during sea-level rise and overwash fluxes, with the morphodynamic model being able to simulate complex barrier behaviours, including rollover, drowning and discontinuous retreat.

On decadal scales, morphological changes in barrier islands are frequently conceptualized using sediment budget approaches, which analyse the sediment balance and transfer pathways of the relevant constituent landforms of the coastal system (French et al., 2016a). Developed using a combination of physics-based and empirical approximations, sediment budget approaches can be included in the morphodynamic morphological-behaviour suite of models, given their geometric simplification of barrier system configuration and numerical treatment of a restricted number of processes. Recent examples include the profile model of Rosati et al. (2010), which simulates decadal barrier migration over compressible substrates to investigate the impact of sediment compaction in barrier evolution; the sediment balance model of Aagaard and Sorensen (2013), which integrates longshore and cross-shore sediment transport to determine long-term evolution of a barrier system; and the profile response model of Larson et al. (2016), which focuses on sediment exchanges driven by dune erosion and overwash, aeolian transport and bar-berm coupling. These models generally concentrate on the intertidal to subaerial domain, where long-term observations are available for calibration.

Based on detailed hydrodynamic fluid motions and physics of sediment transport, 2D and $3 \mathrm{D}$ process-based numerical models have been widely used in the coastal and marine engineering community (Fagherazzi and Overeem, 2007). Improvements have been made with established process-based models to widen their spatial and temporal range of applicability, including improved morphodynamic upscaling with the morphological acceleration factor implemented in Delf3D (Lesser et al., 2004; Roelvink, 2006; Ranasinghe et al, 2011), or coupling diverse model suites (e.g ROMS, SWAN, XBeach) for regional scale simulations (Warner et al., 2008, 2010; 
Barnard et al., 2014). However, non-linearity, internal dynamics, free and forced dynamic responses to stochastic conditions are not adequately captured by models that simulate flows and sediment transport processes at high-resolution and very short time-steps. This limits the use of process-based models for addressing mesoscale evolution of barrier-lagoon systems (Moore et al., 2010; Carrasco et al., 2016; Ruggiero et al., 2016), irrespective of whether meaningful schematization has been undertaken of input conditions (Cayocca, 2001).

Recent efforts have been made to couple diverse model types to create integrated modelling frameworks that address decadal to centennial-scale evolution of whole stretches of coast (French et al., 2016b; van Maanen et al., 2016). The CoSMOsCOAST modular model of Vitousek et al. (2017) is a recent example of this hybrid approach, combining historical data assimilation with process-based models of crossshore and longshore sediment transport to simulate long-term shoreline position along sandy barriers.

\section{Geological influences on mesoscale barrier behaviour}

The geological influence on barrier behaviour in millennial scale stratigraphic studies is well established (e.g. Riggs et al., 1995; Schwab et al., 2000) but, until recently, this has been less clear in investigations of mesoscale barrier behaviour. Investigations using historical, geological and modelling approaches, and taking advantage of advances in chronological control and spatial measurement, now reveal that a variety of geological factors do influence barrier morphology and behaviour at the mesoscale (e.g. Honeycutt and Krantz, 2003; Lentz and Hapke, 2011; Houser, 2013; FitzGerald, 2015).

These can be visualized in a systematic view of the barrier/lagoon environment (Fig. 12). Barrier/lagoons are open systems that involve inputs of energy (via dynamic variables such as waves, tides, and wind) and sediment (a geological variable), which can be positive or negative. Within the system boundary (which is set by the surrounding geological framework), a particular barrier morphology develops whose subsequent behaviour is then influenced by a variety of geological controls. Thus, mesoscale barrier/lagoon behaviour is influenced both by inherited geological factors 
that control the initial barrier morphology and geological factors that influence ongoing changes.

Many of these elements (particularly relating to surface morphology) are readily quantifiable using available and widely employed techniques (airborne LiDAR, multibeam bathymetry), but others (chiefly relating to sub-surface geology) require approaches that are common in geological/stratigraphic studies but which are only occasionally applied in studies of mesoscale barrier/lagoon behaviour (e.g. Costas et al., 2006). Increased recognition of the resolution available in contemporary geological investigations such as those described above, is likely to lead to more frequent application of those techniques in mesoscale studies.

Several potentially important geological parameters are interrelated and consequently a tentative hierarchy is here proposed (Fig. 13). This identifies the primary geological controls as the basement characteristics (slope, topography and erodibility), shoreface morphology and sediment supply. Lithification is also a locally important primary control, particularly in the tropics where beachrock and aeolianite formation occurs in barriers (Cooper, 1991).

These primary controls influence secondary geological controls such as barrier and lagoon extent and orientation, barrier volume and morphology (especially height and the extent to which overwash is possible), barrier planform morphology (swash- or drift-aligned), the tidal prism and thereby the size and abundance of tidal inlets. Dealing with them separately is a somewhat artificial exercise, however, by reference to examples, the role of the primary controls and the network of linkages to subordinate levels of geological and dynamic control are outlined below.

\subsection{Basement slope}

Many studies have shown a relationship between basement slope and rates and patterns of barrier migration. Geological investigations (e.g. Belknap and Kraft, 1985) have shown that the antecedent slope controls the relative accommodation space available for a migrating barrier and largely influences whether in-place drowning, rollover, erosion or accretion occurs. Schwab et al. (2000) found that barrier islands 
resting on a steeper transgressive ravinement surface migrated landward at a faster rate than those on flatter surfaces. The palaeo-slope on which contemporary barrier islands rest, also influences contemporary wave dynamics on the barrier shoreface. Steeper palaeo-slopes were found to produce thinner shoreface accumulations due to differential changes in wave refraction (Riggs et al., 1995). Roy et al. (1994) found a critical retention threshold at an antecedent gradient of $1^{\circ}$; slopes steeper than this promoted the offshore loss of sandy sediment. On flatter slopes, sandy sediment was moved onshore into the littoral zone where it became accessible to the barrier shoreface. This relationship is likely enhanced in regressive barrier systems where local progradation of the barrier front may cause steepening of the shoreface and net seaward sediment loss from the shoreface over time.

Salzmann et al. (2013) and Green et al. (2018) highlighted the role of antecedent slope in the preservation and response of barriers to mesoscale sea-level rise. Steeper slopes provided a limited accommodation that caused barriers to aggrade during sealevel stillstands. However, the steeper slopes also focused shoreface erosion more effectively as sea-levels subsequently rose, with a greater amount of erosion per unit of time (e.g. Cattaneo and Steel, 2003).

Hapke et al. (2016) showed that the long-term shoreline change pattern alongshore was influenced by variations in slope of the beach (Lentz et al., 2013), sediment availability and bathymetric features on the inner continental shelf (Hapke et al., 2010; Schwab et al., 2000, 2013). They were able to statistically demonstrate the influence of processes constrained by framework geology on barrier island evolution at the mesoscale.

Brenner et al. (2015) examined the role of antecedent topography on barrier evolution on Metompkin Island, Virginia. In a hindcast study of subaerial barrier modification with rising sea levels, they considered a wide back barrier the most important variable to affect the island migration trajectory (i.e. roll over, in place drowning or erosion). Rather than the straightforward basement slope, they found that the back-barrier width modulated the slope relationship as it dampened the migration rates due to sediment scavenging from a sandy back-barrier and associated changes in backbarrier width. This points to the antecedent substrate type and back-barrier antecedent 
conditions as perhaps the most important control on barrier response to sea-level rise (Moore et al., 2010).

The application of several investigative models (Murray, 2003) has greatly advanced the understanding of underlying slope control on barrier evolution as well as some of the interactions and feedbacks. These investigative approaches evolved from early applications of Bruun Rule-type profile responses on an infinitely erodible and homogenous coastal plain (Cowell et al., 1995) through variations that allowed the effect of a heterogenous underlying geology to be investigated (Stolper et al., 2005 Valvo et al., 2006; Hapke et al., 2010; Moore et al., 2010). Similarly, modelling of shoreline planform evolution (Wolinksy et al., 2015; Valvo et al., 2006) has allowed the role of underlying lithology of varying composition to be assessed.

Most conceptual diagrams of basal slope over which a barrier is transgressing depict it as a continuously sloping surface (e.g. Cowell and Kinsella, 2018). While the slope of the area that has already been transgressed (i.e. seaward of the barrier) can readily be assessed, the area landward of the contemporary barrier cannot be regarded as a straightforward continuation of that slope (see below). It has yet to be transgressed and subject to the processes of wave ravinement that produced the basal surface to seaward. Its geology and topography will influence how that surface evolves with ongoing transgression.

\subsection{Basement Topography and erodibility: Headlands, cliffs, depressions and topographic highs}

When resistant basement material is present in the surface being transgressed, irregularities (topographic highs and lows) significantly influence the morphology and behaviour of barriers (Demarest and Leatherman, 1985; Wolinsky and Murray, 2009) and backbarriers via control on accommodation space (Storms et al. 2008; Koster et al., 2017) (Fig 1B). Indeed, according to Beets and van der Spek (2000, p.8) "The size of the back-barrier basin, which is a function of the slope of the pretransgressional surface, and the rate of RSL rise are the main factors defining the accommodation space". Headlands act both as anchor points and sources of sediment for barriers. With slowly rising or stationary sea levels, they help fix the position of 
barriers (Orford et al., 2002) and subsequent shoreline evolution may lead to development of swash- or drift-aligned planforms.

An extreme example of bedrock influence on barrier behaviour is evident in the barrier islands of the Outer Hebrides of Scotland (Cooper et al., 2012). Here, a 70 km-long chain of sandy barriers rests on a broadly planar surface of Precambrian gneiss. The bedrock surface dips seaward at between $0.001^{\circ}$ and $0.002^{\circ}$ from $+30 \mathrm{~m}$ to $-100 \mathrm{~m}$ MSL. Glacial modification of the bedrock surface has created depressions of various sizes (Dawson et al., 2013). Modern sandy barriers migrate landwards over the bedrock surface by overwash and aeolian deflation and their planform is much influenced by bedrock topography (Fig 13). Two main types of barrier island morphology exist within the chain. In bedrock depressions (Figure 13B) the barrier island has a shoreface and is backed by a lagoon with sufficient tidal prism to maintain an inlet and associated ebb- and flood-deltas. In areas of high bedrock topography, (Figure 13A) the barrier island lacks a shoreface and the impounded back-barrier water body lacks tidal inlets due to the limited basin size. As the barriers migrate across the essentially unerodible bedrock surface they encounter areas of low and high backing topography that determines which morphology is adopted by the barrier island. In this setting, bedrock topography is the primary determinant of barrier response to environmental change.

Barrier sediment may be sourced from erosion of the underlying substrate (e.g. Belknap and Kraft, 1985; Riggs et al., 1995). The profusion of fossil shark teeth in barrier sediments of North Carolina (Pilkey et al., 2004), and Pleistocene mammal bones on the Lagoa dos Patos barrier in Brazil (Lopes and Buchmann, 2011), testify to a portion of barrier sediment being derived from erosion of underlying sediments. The nature of the erodible material also influences the texture of the derived sediment. Where underlying palaeo-valleys are transgressed and a headland is exposed on the shoreface, coarser sediment may be liberated from the headland than from intervening valleys (e.g. Belknap and Kraft, 1985). "The lithology of the underlying units exerts a primary control on the distribution, texture, and composition of surficial sediments, as well as inner-shelf bathymetry" Thieler et al. (2001, p 958). Murray and Moore (2018) explicitly considered the influence of erodible seabed material on shoreface and barrier morphology under rising sea-level. In model studies they showed how the 
influence can be quantified according to the relative proportions of fine and coarsegrained sediment yielded by erosion as the shoreface erodes into former back-barrier sediments. There are, however, few quantified field reports of the nature of the actual material being eroded through such erosion.

The rate of sea-level rise can also influence the degree to which underlying geology affects barrier evolution. In a comparative study of gravel barriers experiencing different rates of sea-level rise Carter et al. (1989, p.221) showed that "In Ireland [slow sea-level rise], barrier-lagoon form is controlled by local basement expression, particularly through the emergence of headlands .... [while]... the Nova Scotian examples [fast sea-level rise] are associated with rapidly moving erosional fronts, with local basement control relegated to a subordinate role at the expense of rapid changes in sediment supply"

\subsection{External sediment supply}

"Barrier island response to changing conditions is likely to be complex and variable, and will be determined, in part, by the rate of sand supply" (Brenner et al., 2015, p. 334)

Sediment is supplied to barriers from diverse sources that largely reflect the environmental setting (Fenster et al., 2016; Ruggiero et al., 2016). The rate of sediment supply is difficult to quantify (mainly because of temporal and spatial variability: it can also be strongly episodic) and often historical data are absent. Although sediment budgets have long been applied in studies of mesoscale barrier behaviour (e.g. Pierce, 1969; Kana, 1995) there are significant uncertainties regarding volumes, sources and supply rates.

The shelf and shoreface are perhaps the most common sources of barrier sand (Schwab et al., 2013), but fluvial sources dominate on deltaic and high-relief coastlines (Cooper, 1990), while cliff erosion is prevalent on paraglacial gravel barriers (Orford et al., 1991). The rate and nature of sediment supply to barriers not only influence their overall morphology (Fig. 2) but are also key constraints on their mesoscale evolution (Fig. 12). Former sediment supply conditions during barrier 
initiation or stabilization may differ markedly from contemporary conditions. Ferreira et al. (2016) distinguished four stages of barrier development for the Ria Formosa barrier in Portugal as sediment accumulated. Stage 1 involved low elevation barriers dominated by overwash that maintained or widened the barrier. Stage 2 involved aeolian transport and vegetation expansion and reducing overwash frequency. Stages 3 and 4 correspond to development and expansion of the foredune, respectively. Barrier volume increased significantly from stages 1 to 3 , with a negative sediment balance and barrier narrowing leading to reduced volumes in stage 4. The different stages can be seen in contemporary barriers of the Ria Formosa, and their evolution is not necessarily sequential, as it depends on the accommodation space provided by the topographic configuration of the system, inlet dynamics, sediment availability and (latterly) human interference.

In longshore drift-dominated barriers, continued sediment supply is necessary to sustain barrier integrity as evidenced by the dramatic effects of groyne and jetty construction on downdrift systems (e.g. Wijnberg, 2002). The influence of changing sediment supply is well illustrated in gravel barrier planform models (Fig. 5) where a reduction in supply can prompt reorganization of the barrier leading to stretching, cannibalization, cell development and ultimate breakdown (Carter et al., 1987), processes that can be reversed with a fresh influx of sediment. Murray and Moore (2018) show how convergences and divergences of longshore drift sediment delivery cause barriers or sections of barriers to advance or retreat, respectively, under sealevel rise.

Episodic sediment supply to barriers is exemplified by river floods (Cooper, 2002) which may cause initial barrier erosion followed by rapid progradation as floodderived sediment is reworked landward under wave action (Cooper, 1990). The reverse effect is well illustrated by damming of rivers in the US West coast which cut the sediment supply and led to barrier retreat (Warrick et al., 2014). Storms are often linked to loss of sediment from barriers or to overwashing depending on the circumstances (Sallenger, 2000; Donnelly et al., 2001), however, Fruergaard et al. (2013) showed that extreme storms can also access sources of sediment on the seabed leading to progradation and formation of new islands. In the example they documented in southern Denmark, an entirely new chain of barrier islands formed in 
the North Sea following an influx of marine-derived sediment after a severe Medieval storm.

The sediment supply strongly influences coastal dynamics on barriers (Fenster et al., 2016). It is also a key determinant of barrier volume, and this in turn, exerts further controls on barrier behaviour (Jennings et al., 1998). Barrier inertia (Orford et al., $1995 ; 2002)$ is a determinant of how rapidly a barrier can be reorganised in response to external forcing and it is a function of sediment volume as measured by barrier cross-sectional area.

Not only the total barrier volume but its morphology, is important. This is seen most readily in whether a barrier is low enough to permit overwash and thereby roll landwards. However, even relatively small variations in dune crest height (Houser, 2012, 2013), or foreshore morphology (Matias et al, 2014) have been shown to modulate overwash vulnerability and barrier migration. Miselis and McNinch (2006) found that nearshore sediment thickness was a strong determinant of barrier shoreline stability.

Large-volume barriers exist on many coasts including southern Brazil (Dillenberg and Hesp, 2009) and SE Africa (Cooper and Pilkey, 2002; Benallack et al., 2016). Most of these barriers are too wide $(7 \mathrm{~km}$ in Brazil) or high $(80-100 \mathrm{~m}$ in Africa) to permit overwash. Consequently, they do not migrate, although sediment may accumulate on them or pass across them via aeolian activity. Conversely, small-volume barriers can evolve very quickly. Sustained shoreline recession rates of 20 to $30 \mathrm{~m}$ per year were noted on low volume barriers in Chesapeake Bay (Cooper, 2013) and the Mississippi Delta (Penland et al., 1985).

Temporal changes in sediment supply can be manifest in sandy barrier morphodynamics at timescale ranging from instantaneous in the case of river floods (e.g. Cooper, 1993) to decadal and centennial in longshore-drift-dominated systems.

\subsection{Coastal orientation/aspect}


The coastal orientation and aspect are often inherited factors determined by the geological surface on which contemporary coastal systems are developed. They are influenced by long-term geological processes related to tectonics, glaciation and longterm weathering patterns. The inherited coastal orientation, in turn influences the degree of exposure to wave and current action and the extent to which barriers are subject to longshore or cross-shore processes. On barrier/lagoon coasts with many headlands, cross-shore effects tend to dominate, whereas on coastal plans, longshore drift predominates. Wijnberg (2002) showed how coastline orientation influenced exposure to the prevailing offshore wave climate and exerted significant influence on decadal scale barrier behaviour. Orientation is also a key influence on reworking of lagoon barrier margins (McBride et al., 1995; Ashton et al., 2009).

\subsection{Shoreline lithification (beachrock/aeolianite formation)}

Lithification of barrier sediments as beachrock and aeolianite is particularly prevalent in the tropics and subtropics (Davies, 1980; Vousdoukas et al., 2007), but is also increasingly recognised in temperate latitudes (e.g. Cooper et al., 2017). It is a locally important primary-level control on barrier behaviour (Cooper, 1991). Cementation (usually by carbonate mineral precipitation between the beach/dune grains) can take place rapidly, and certainly occurs at decadal/century timescales (Vousdoukas et al., 2007; Mauz et al., 2015). Cementation in barriers has the immediate effects of removing sediment from the active littoral budget, reducing porosity and creating resistant geological elements (headlands and platforms) that exert a direct geological influence on subsequent barrier behaviour (Cooper, 1991; May et al., 2012). The cemented material itself then undergoes breakdown under wave action (e.g. Cooper and Green 2016) and its preservation potential depends on the rate of submergence and its resistance to wave-induced erosion. Even when submerged, continued erosion of overstepped cemented barriers can occur through direct wave action and stormreturn flows (Pretorius et al., 2018).

Multibeam bathymetry has revealed spectacular and widespread occurrences of beachrock and aeolianite-cemented shorelines in the Gulf of Mexico (Jarrett et al. 2005; Gardner et al., 2005, 2007), the southwest Indian Ocean (Green et al., 2018; Salzmann et al., 2013) and the Mediterranean Sea (de Falco et al., 2015), where they 
preferentially preserve former shorelines through their resistance to erosion during subsequent sea-level rise.

\subsection{Shoreface morphology}

Although many shorefaces are mobile and to that extent, dynamic features, the timescales of significant morphological change on the shoreface are typically much longer than those on adjacent barriers (Swift et al., 1985; Ruggiero et al., 2005), rendering them geological controls at the decadal to century timescale. Shoreface morphology is an important geological influence on mesoscale shoreline behaviour (Riggs et al., 1995; Wijnberg, 2002). Indeed, Cowell and Kinsella (2018) argue that shoreface processes are a fundamental control on barrier form and behaviour. Shoreface morphology is itself strongly controlled by the underlying geology (Riggs et al., 1995; Thieler et al., 1995) and sediment supply and is therefore an intermediate level geological control on barrier behaviour (Fig. 13).

Riggs et al. (1995) showed that underlying geology created six different shoreface morphologies along the North Carolina coast, the primary distinction being between shorefaces underlain by relict headlands (interfluves) or incised valleys. They noted (p.213) that "stratigraphically-controlled bathymetric features on the inner shelf modify waves and currents and thereby affect patterns of sediment erosion, transport, and deposition on the adjacent shoreface." Working at decadal timescales, Wijnberg (2002) showed shoreline behaviour along the Holland coast was strongly influenced by adjacent shoreface morphology, particularly the occurrence of shoreface-connected ridges (SCRs). These quasi-stationary features have also been linked to the development of long-term coastal concavities, for example on Fire Island, NY (Safak et al., 2017).

\section{The role of initial barrier morphology}

The geological factors outlined above, in combination with the prevailing dynamic regime, create barrier islands of varying morphology. In any study of geomorphological change, the initial morphology is a key determinant of the direction and rate of future travel. This is most immediately evident during storms when the 
differential responses of barriers can readily be linked to pre-existing morphology (Kahn and Roberts, 1982; Sallenger, 2000; Matias et al., 2008; Masselink and van Heteren, 2014), but pre-existing morphology also influences the nature of longer term geomorphic feedbacks on barrier systems (Houser, 2012, 2013). To this extent, the geomorphic form of any barrier is an important constraint in its future behaviour (Houser et al., 2017). The diversity of barrier forms outlined above thus implies a multiplicity of mesoscale behaviours.

Several studies have demonstrated complex links between initial barrier morphology and decadal scale evolution. The following two case studies serve to illustrate.

Houser et al. (2008) studied the morphology and mesoscale behaviour of Santa Rosa Island, FL. The island exhibited systematic variation in dune crest elevation at several length scales. Analysis showed that these correlated with transverse ridges on the inner shelf, backbarrier cuspate features and historic rates of shoreline change. The work demonstrated that the inner shelf ridges influenced the elevation of dunes on the barrier island through their impact on wave refraction and focusing. This variation in dune crest height in turn caused alongshore variation between sectors that experienced offshore sand loss (high dunes) and those that experienced overwash (low areas) during storms. The post-storm recovery reinforced this spatial difference with low, overwashed areas close to the water table, experiencing lower rates of subsequent dune growth. In contrast, high dune areas that had lost sand to the adjacent shoreface, regained it and rebuilt high dunes in the post-storm period. The historical rates of shoreline change strongly correlated with island width and foredune height. The linkages between these morphological features led Houser et al. (2008, p.238) to conclude not only that foredune morphology profoundly affected barrier response to storms, but also that "the height and extent of foredune development and the presence and relative location of the backbarrier dunes are "geologically" controlled and reinforced during successive storms"

Mesoscale changes on a stretch of the NW French coast show a strong link between shoreface morphology, seabed sediment supply and barrier behaviour (Anthony, 2013), demonstrating again the importance of the immediately antecedent barrier and nearshore morphology on barrier behaviour. In the study area, a series of wide, dune- 
topped barriers are fronted by a topographically irregular but low gradient shoreface that contains a set of large-scale tidal sand bars and ridges elongated parallel to the shore. These form a nearshore depocentre where sediment from the North Sea accumulates. Episodic welding of these tidal sandbars to the barrier cause the beach to widen, creating a backshore sand flat on which embryo- and then foredunes develop at a timescale of several decades. Bar welding and dune growth is associated with wave dissipation offshore on the submerged section of the welded sandbar. Additional sediment is delivered to the barriers by the welding of smaller shoreface features including sandwaves and subaqueous dunes, all of which are driven by storm activity.

Unsurprisingly, the historic patterns of shoreline change show marked alongshore variability. Some areas are retreating at $>8 \mathrm{~m} /$ year while others have prograded at up to $2 \mathrm{~m} / \mathrm{yr}$. The differences in shoreline behaviour are linked to the relationship between nearshore sandbars and the barriers and the way in which this relationship is mediated by storms. Areas of beach progradation and active foredune growth occur where sand banks welded onshore under the influence of storms. The onset of erosion in areas that were historically progradational are attributed to interactions between offshore banks, storms, longshore sand transport and possible current gyres generated by a projecting rocky headland. Amongst other processes, lowering of the bar crest, and increased onshore wave energy leads to shoreline erosion. Anthony (2013) remarked on the spatial variability in storm barometric pressure, wind velocity, set-up and tidal stage that, coupled with the marked variability in barrier-nearshore morphology, rendered the response to storms, spatially variable and entirely unpredictable.

Although these case studies come from vastly different barrier settings, both clearly demonstrate (i) the morphological links between shoreface and barrier morphology and behaviour, (ii) the different temporal scales of morphological change on barrier and shoreface, (iii) the complexity of barrier response to storms and (iv) marked spatial variability in mesoscale barrier behaviour and rates of change. In both instances, any effort to predict future barrier behaviour would require a detailed initial assessment of the barrier and nearshore morphology. 


\section{Discussion}

Following a long period during which the dominant research theme in mesoscale barrier behaviour was focused on linkages between dynamics and response (morphodynamics), appreciation of the important influence of geological inheritance has increased in the past two decades. This appreciation has built upon and extended insights from early stratigraphic studies that had millennial scale resolution. It is, however, now clear that geological inheritance also significantly influences barrier behaviour at decadal/centennial scales. This influence is asserted directly and indirectly through:

(a) barrier morphology at the beginning of the period of investigation $\left(\mathrm{t}_{0}\right)$;

(b) underlying attributes of the surface upon and/or over which the barrier is evolving $\left(\mathrm{t}_{1}-\mathrm{t}_{\mathrm{x}}\right) ;$ and

(c) sediment supply which can be an internal or external geological influence.

Recognition of the role of geological inheritance has been derived in part from traditional, historical scale investigations that are now benefitting from enhanced temporal databases of morphological change and potential drivers. In addition, traditional geological methods (stratigraphy and coring) that could formerly only achieve millennial scale temporal resolution are now yielding centennial and even decadal scale insights into barrier behaviour. Since these often come from the Holocene record, they allow the role of the underlying geology to be inferred. They also cover a wider variety of sea-level scenarios and environmental settings than are observable at the present. Improved investigative modelling is enabling potential geological controls on mesoscale barrier evolution to be studied and compared to findings from historical and geological investigations. In combination, the many historical, geological or modelling studies demonstrate the often critical influence of geological factors in moderating or steering barrier behaviour. Added to this is the documentation of many diverse barrier types around the world, whose morphology is clearly a primary determinant of their behaviour (high, dune-topped barriers do not overwash, for example). 
Recent developments in the understanding of mesoscale behaviour and the extent to which they are influenced by geological controls (e.g. shoreface-barrier decoupling; and the influence of the often irregular surface being transgressed), indicate that some of our conceptual and analytical models are oversimplified, incomplete or erroneous. Shoreface translation is far from ubiquitous and the role of underlying topography is far greater than supposed.

With acknowledgement of the role of geological factors, comes the challenge of incorporating them into future studies, firstly to aid the interpretation of past mesoscale behaviour and secondly to predict future response to climate and sea-level change in particular. Measurement and quantification of geological controls has long been possible with geophysical methods, both marine and terrestrial. The more recent advent and increased application of multibeam bathymetry and LiDAR technology enables quantification of contemporary morphology at resolutions that were previously inconceivable. This helps quantify the contemporary morphology as a starting point for consideration of future mesoscale behaviour. Studies such as those discussed above in Lake St Lucia, South Africa and the Pamlico Sound, NC demonstrate the utility of geological investigations to yield century- and even decadescale resolution. However, adequate quantification of contemporary morphology (barrier topography, nearshore and lagoon bathymetry) and underlying geological control (bedrock morphology, type, sediment volume, thickness, type etc) to fully constrain models of future shoreline behaviour (i.e. to define the geological controls) exists in only a few barrier lagoon systems. Notable examples include Fire Island, NY, which has been the focus of detailed USGS investigation (Schwab et al. 2017) and Galveston island, TX (Wernette et al., 2018), where historical data augmented with new barrier investigations enabled a rare quantification of the linkage between antecedent geology and contemporary form. In the Netherlands, an abundance of subsurface data enabled construction of a 3D assessment of Holocene base level rise in two tributaries of the Rhine-Meuse system (Koster et al., 2017). Such locations offer an opportunity to assess the role of some geological factors, but their limited diversity means that other parameters cannot yet be studied, other than by modelling.

Of key importance to coastal management is the desire to predict future barrier position and status under various scenarios. This is traditionally undertaken by 
morphodynamic modelling that takes little account of geological inheritance. While this was dismissed as an essentially millennial scale influence or local 'noise', we now know that geological inheritance potentially exerts control on hydrodynamics themselves and both the long- and/or short-term responses to hydrodynamic forcing. As noted by Wijnberg (2002 p. 227) “... detailed comparison of alongshore variation in environmental variables along the Holland coast with the observed marked regional differences in decadal nearshore morphologic behaviour reveals that neither offshore hydrodynamic parameters nor grain size are discriminating factors". In a similar vein, Lorenzo-Trueba and Ashton (2014, p.779) state that "barrier response can be particularly sensitive to the sea-level rise rate and back-barrier lagoon slope. Overall, our findings contrast with previous research which has primarily associated complex barrier behaviour with changes in external forcing such as sea-level rise rate, sediment supply, or back-barrier geometry".

Much progress has been made in understanding the role of geological parameters in barrier behaviour. However, there remains a disconnect between this understanding and the operational area of coastal management and modelling in support of this goal. Geological influences are routinely overlooked. Modelling approaches (e.g. Zhang et al. 2010, 2012; Jimenez and Sanchez-Arcilla, 2004; van Maanen et al., 2015) that seek to apply deterministic, process-based models to predict coastal behaviour in the absence of an appreciation of geological control hold little potential to improve understanding of or predict barrier-lagoon behaviour. As noted by Valvo et al. (2006, p. 12) "quantitatively accurate modelling of sediment-poor coastlines will remain an elusive goal for the foreseeable future". Efforts to link such models and create ever more complex models (e.g. Van Maanen et al., 2015) are simply exercises in modelling rather than attempts to understand system behaviour; they hold no prospect for improving predictions of decadal scale behaviour and contribute only a false sense of confidence to coastal managers. Future research should focus on incorporating important geological influences into modelling efforts. The few sites described above for which adequate data exist provide ready yardsticks against which new models may be compared.

Sensitivity to initial conditions is known to be a critical issue in modelling and yet, modelling efforts often lack adequate description of initial conditions. Knowing the 
starting conditions for any modelling exercise is known to be critical, and parameters such as the depth to bedrock, the vertical and lateral variations in sediment character (that are temporally variable) are either totally unknown, or at best, incompletely described or parameterized in modelling studies. Several studies have demonstrated complex links between initial barrier morphology and decadal scale evolution. These serve to illustrate the critical importance of initial barrier state in any future forecasting of mesoscale behaviour. These geological parameters might be capable of measurement by, for example, use of a dense grid of high-resolution geophysical investigations, but they are not currently given serious consideration in most applied studies. Geological data at adequate resolution to assess its influence is unfortunately lacking, nor is it given serious consideration in most shoreline prediction efforts. Furthermore, the quantification of sediment supply in the mesoscale remains an issue because of the variability of sources, temporal variability in supply, variations in source and sink areas within a barrier system, and the difficulty in measuring sediment supply (Cooper and Pilkey, 2004b).

Quantification of the geological framework is essential to understanding decadal to century scale evolution of barrier-lagoon coasts and should be a basic requirement of investigations of future shoreline behaviour. Tools exist to undertake the necessary investigations and the evolution of new mapping technologies (e.g. Pavlis and Mason, 2017) emphasize the potential to incorporate geological parameters into models of mesoscale behaviour of barrier/lagoon systems. The geological framework and morphology of barriers is strongly site-specific and simulating their future mesoscale evolution requires that it be measured. While morphological behaviour models have provided insights into barrier behaviour and have enhanced our understanding of interactions that are difficult to observe or quantify, they rely on simplifications (e.g. sediment mass conservation or barrier cross-section schematization) that preclude their use as quantitative predictive tools in the real world. As a consequence, the prediction of future barrier behaviour will necessarily remain in the qualitative domain. The apparent high-resolution and accuracy claimed by morphodynamic modelling studies is not real. Neither can morphological behaviour models deliver quantitative predictions. They do, however, allow qualitative assessment of future barrier condition. Coastal managers must be reconciled to the need to base decisions on such qualitative projections. 


\section{Acknowledgements}

This work is a contribution to IGCP Project 639 'Sea-level change from minutes to millennia' and to the EU H2020-MSCA NEARControl project, which received funding from the European Union's Horizon 2020 Research and Innovation programme under the Marie Skłodowska-Curie grant agreement No. 661342. We thank Kim Cohen for discussion of the Netherlands shoreface history. We have benefitted over the years from numerous discussions on geological controls with Orrin Pilkey, Joe Kelley, Dan Belknap and Derek Jackson. 


\section{Figure Captions}

Figure 1. A. Unconstrained barrier island facies model (after Reinson, 1992); B. Barrier island facies model showing geological influences and resulting morphological variations.

Figure 2. Barriers exist in many diverse settings and exhibit vastly different morphology and dimensions. These both derive from a combination of dynamics and geological influences, and impart key constraints on future barrier behaviour. Various sizes of barriers are depicted here. Note the variation in scale. A. Pamlico-Albemarle system, USA, a multiple inlet system with small barrier volumes; B. Lagoa dos Patos, Brazil, a single inlet system with a wide and low barrier; C. St Lucia lagoon, South Africa, a single inlet system with a very high barrier; D. Ria Formosa, Portugal, a multiple inlet system; E. Frisian Islands, Netherlands and Germany, a multiple inlet system with generally prograding/aggrading barriers). F. comparative cross-sections at a common scale show the contrasts in morphology and setting of these systems (arrows mark the barrier position). The Outer Banks, Patos Lagoon and Frisian Island systems are in low gradient, coastal plain settings with wide continental shelves. The St Lucia and Ria Formosa systems are on steep bedrock coasts fronted by narrow continental shelves.

Figure 3. Profile models of barrier response: A. Rollover; B. Erosion/Bruun Rule; C. Overstepping; D. Progradation/aggradation (Adapted from Mellet et al., 2013)

Figure 4. Chesapeake Bay fetch-limited barrier profile evolution. The barrier migrates over a backing marsh which is exposed on the foreshore. During exposure of the marsh the barrier detaches from the shoreface and continues to migrate across the marsh surface until it is beyond effective wave reach. Erosion of the exposed marsh continues until it is removed and the barrier and shoreface are again united. (After Cooper, 2013)

Figure 5. Gravel barrier planform behaviour model. (A) An initial prograding barrier/spit is supplied with sediment from alongshore. (B) External sediment supply is reduced and sediment begins to be eroded from the updrift end of the barrier (cannibalization). Deposition of eroded material leads to development of littoral cells 
as the barrier strives for equilibrium with incident waves. (C) Cell development and continued sediment starvation cause the barrier to breach (After Carter et al., 1987).

Figure 6. Rapid morphological evolution of a fetch-limited barrier on the western shores of Virginia. The barrier evolution follows the model of gravel barrier planform development in Figure 5. A. Initial barrier morphology (1994). B. Sediment influx generates an alongshore elongation of the barrier across a coastal reentrant (2005). C. Sediment starvation leads to cell development (2007). D. The barrier stretches and breaches (2008).

Figure 7. Generalized 8-mode geomorphic response-type model for Gulf of Mexico sand and barriers (inspired by McBride et al. 1995). Arrows depict shoreline direction of change and resulting planform changes. Upper panels represent time t0, while lower panels represent future time t1. Primary response modes are: lateral (alongshore) movement; advance (cross-shore); retreat (cross-shore); dynamic equilibrium (cross-shore stability). These, in combination, lead to more complex modes: in-place narrowing; landward rollover; break up; and rotation. Barrier A is accreting at one end and eroding on the other. Lateral variations in cross-shore behaviour are causing the island to rotate counter clockwise. Sediment supply from lateral erosion favours accretion at one end and erosion at the other. Barrier B is exhibiting landward rollover accompanied by some lateral movement. Overall, the sediment volume of the barrier is maintained. In Barrier $\mathrm{C}$ lateral movement and bayside and oceanside erosion cause the barrier to break up and disintegrate.

Figure 8. 19-year time series of images of Shanks Island, VA in Chesapeake Bay. An initial barrier island chain is gradually broken up as the islands lose volume, in the absence of an ongoing sediment supply. The island chain is progressively eroded and converted into a series of subtidal shoals.

Figure 9. 3-D model of barrier/lagoon evolution under sea-level rise. An initially stable system is progressively affected by rising sea level. In this model, back-barrier marshes are unable to accrete at the same rates as sea-level rise. The tidal prism thus increases, and the inlet and tidal delta volumes increase at the expense of the barrier 
islands. Ultimately, the barrier islands decay and the sediment from both islands and deltas is reworked landward (FitzGerald et al. 2006).

Figure 10. Shoreface-barrier linkages: shoreface retreat modes. A. Barrier and shoreface retreat at equal rates (keep-up). B. Shoreface retreat slower than barrier migration (give-up); C. shoreface 'catch-up'.

Figure 11. Conceptual schematization of the different morphological-behaviour model approaches; a) STM morphokinematic model (adapted from Cowell et al., 1995); b) GEOMBEST + relaxed morphokinematic model (adapted from Walters et al., 2014); c) BARSIM morphodynamic model (adapted from Storms et al., 2008).

Figure 12. System view of barrier island system showing linkages between energy and sediment inputs, initial state and geological constraints, and response conditioned by geological constraints.

Figure 13. Hierarchy of geological controls on mesoscale barrier behaviour. First order controls are inherited geological controls independent of dynamics. These influence second order controls (morphological parameters) of barriers. An intermediate level of geological control is exerted by the shoreface, which, although dynamic, tends to evolve at longer timescales than adjacent barriers, thus rendering the shoreface a geological control.

Figure 14. Hebrides barrier islands, western Scotland. These barrier/lagoon systems, developed on resistant bedrock are and end-member in terms of the influence of underlying geology on barrier morphology and behaviour and provide a graphic illustration of bedrock control. Barrier planform morphology is clearly influenced by bedrock outcrop throughout the barrier island chain, creating, for example, swashaligned barrier sections between headlands and cuspate shoreline features or tombolos in the lee of offshore outcrops. Two distinctive morphological types are present, depending on the elevation of the bedrock over which the barrier is migrating. In topographically high areas (A), barriers enclose small, perched lagoons with insufficient tidal influence to create inlets. In areas of low bedrock elevation, backbarrier basins are larger and tidal circulation creates inlets and associated deltas (B). 
The primary determinant of future barrier morphology is the bedrock morphology over which it migrates.

\section{References}

Aagaard, T., Sørensen, P. 2013. Sea level rise and the sediment budget of an eroding barrier on the Danish North Sea coast. Journal of Coastal Research, Special Issue, 65, 434-439.

Anthony, E.J., Blivi, A.B. 1999. Morphosedimentary evolution of a delta-sourced, drift-aligned sand barrier-lagoon complex, western Bight of Benin. Marine Geology $158,161-176$.

Anthony, E.J. 2013. Storms, shoreface morphodynamics, sand supply, and the accretion and erosion of coastal dune barriers in the southern North Sea. Geomorphology, 199, 8-21.

Ashton, A.D., Murray, A.B., Littlewood, R., Lewis, D.A., Hong, P. 2009. Fetchlimited self-organization of elongate water bodies. Geology, 37, 187-190.

Ballarini, M., Wallinga, J., Murray, A.S., van Heteren, S., Oost, A.P., Bos, A.J.J., van Eijk, C.W.E., 2003. Optical dating of young coastal dunes on a decadal time scale. Quaternary Science Reviews, 22, 1011- 1017.

Barnard, P.L., van Ormondt, M., Erikson, L.H., Eshleman, J., Hapke, C., Ruggiero, P., Adams, P.N., Foxgrover, A.C. 2014. Development of the Coastal Storm Modelling System (CoSMoS) for predicting the impact of storms on high-energy, active-margin coasts. Nat. Hazards, 74, 1-31.

Beets, D.J., van der Spek, A.J.F. 2000. The Holocene evolution of the barrier and the back-barrier basins of Belgium and the Netherlands as a function of late Weichselian morphology, relative sea-level rise and sediment supply. Netherlands Journal of Geosciences 79, 3-16. 
Belknap, D.F., Kraft, J.C. 1985. Influence of antecedent geology on stratigraphic preservation potential and evolution of Delaware's barrier systems. Mar. Geol., 63, $235-262$.

Benallack K., Green, A.N., Humphries, M. Cooper, J.A.G., Dladla, N. and Finch, J. 2016. The stratigraphic evolution of a large back-barrier lagoon system with a nonmigrating barrier. Marine Geology 379, 64-77.

Brenner, O.T., Moore, L.J., Murray, A.B. 2015. The complex influences of backbarrier deposition, substrate slope and underlying stratigraphy in barrier island response to sea level rise: insights from the Virginia Barrier Islands, mid-Atlantic Bight, U.S.A. Geomorphology, 246, 334-350.

Brock, J.C., Purkis, S.J. 2009. The emerging role of LiDAR remote sensing in coastal research and resource management. Journal of Coastal Research, Special Issue $53,1-5$.

Buizza, R., S. Brönnimann, L. Haimberger, P. Laloyaux, M.J. Martin, M. Fuentes, M. Alonso-Balmaseda, A. Becker, M. Blaschek, P. Dahlgren, E. de Boisseson, D. Dee, M. Doutriaux-Boucher, X. Feng, V. John, K. Haines, S. Jourdain, Y. Kosaka, D. Lea, F. Lemarié, M. Mayer, P. Messina, C. Perruche, P. Peylin, J. Pullainen, N. Rayner, E. Rustemeier, D. Schepers, R. Saunders, J. Schulz, A. Sterin, S. Stichelberger, A. Storto, C. Testut, M.A. Valente, A. Vidard, N. Vuichard, A. Weaver, J. While, aM. Ziese, 2018: The EU-FP7 ERA-CLIM2 project contribution to advancing science and production of Earth-system climate reanalyses. Bulletin of the American Meteorological Society, in press.

Byrnes, M.R., Gingerich, K.J. 1987. Cross-island profile response to Hurricane Gloria. Proceedings Coastal Sediments '87. ASCE, New Orleans, Louisiana, 14861502.

Carapuço, M.M., Taborda, R., Silveira, T.M., Psuty, N.P., Andrade, C., Freitas, M.C., 2016. Coastal geoindicators: Towards the establishment of a common framework for sandy coastal environments, Earth-Sci. Rev., 154, 183-190. 
Carrasco, A.R., Ferreira, Ó., Roelvink, D. 2016. Coastal lagoons and rising sea level: a review. Earth-Science Reviews, 154, 356-368.

Carter, R.W.G. 1988. Coastal Environments. Academic Press, London.

Carter R.W.G., Forbes, D.L., Jennings, S.C., Orford, J.D., Shaw, J., Taylor, R.B. 1989. Barrier and lagoon coast evolution under differing relative sea-level regimes: examples from Ireland and Nova Scotia. Marine Geology, 88, 221-242.

Carter, R.W.G., Orford, J.D., 1981. Overwash processes along a gravel beach in South-East Ireland. Earth Surface Processes and Landforms, 6, 413-426.

Carter, R.W.G., Orford, J.D., 1984. Coarse clastic barrier beaches: A discussion of the distinctive dynamic and morphosedimentary characteristics. Marine Geology, 60, $377-389$.

Carter, R.W.G., Orford, J.D., Forbes, D.L., Taylor, R.B., 1987. Gravel barriers, headlands and lagoons: an evolutionary model. Proceedings of Coastal Sediments '87 (ASCE), 1776-1792.

Cattaneo, A., Steel, R.J. 2003. Transgressive deposits: a review of their variability. Earth Science Reviews, 62, 187-228.

Cayocca, F. 2001. Long-term morphological modelling of a tidal inlet: the Arcachon Basin, France. Coastal Engineering 42, 115-142.

Clarke, D.W., Boyle, J.F., Lario, J., Plater, A.J. 2014. Meso-scale barrier estuary disturbance, response and recovery behaviour: evidence of system equilibrium and resilience from high-resolution particle size analysis. The Holocene, 24, 357-369.

Cooper, J.A.G., 1990. Ephemeral stream-mouth bars at flood-breach river mouths: comparison with ebb-tidal deltas at barrier inlets. Marine Geology, 95, 57-70. 
Cooper, J.A.G. 1991. Beachrock formation in low latitudes: implications for coastal evolutionary models. Marine Geology, 98, 145-154.

Cooper, J.A.G. 1993. Sedimentation in a river-dominated estuary. Sedimentology, 40, 979-1017.

Cooper, J.A.G. 2001. Geomorphological variability among microtidal estuaries from the wave-dominated South African coast. Geomorphology, 40, 99-122.

Cooper, J.A.G. 2002. The role of extreme floods in estuary-coastal behaviour: contrasts between river- and tide-dominated microtidal estuaries. Sedimentary Geology, 150, 123-157.

Cooper, J.A.G., 2013. Mesoscale geomorphic change on low-energy barrier islands in Chesapeake Bay, USA. Geomorphology, 199, 82-94.

Cooper, J.A.G., Green, A.N. 2016. Geomorphology and preservation potential of coastal and submerged aeolianite: examples from KwaZulu-Natal, South Africa. Geomorphology, 271, 1-12.

Cooper, J.A.G., Green, A.N., Meireles, R., Klein, A.H.D.F., Toldo, E. 2016. Sandy barrier overstepping and preservation linked to rapid sea level rise and geological setting. Marine Geology, 382, 80-91.

Cooper, J.A.G., Green, A.N., Wiles, E., 2017. Beachrock genesis and morphology on a paraglacial beach. Sedimentary Geology, 360, 47-63.

Cooper, J.A.G., Jackson, D.W.T., Dawson, A.G., Dawson, S., Bates, C.R., Ritchie, W. 2012. Barrier islands on bedrock: a new landform type demonstrating the role of antecedent topography on coastal evolution. Geology, 40, 923-926.

Cooper, J.A.G., Pilkey, O.H. 2002. Barrier islands of southern Mozambique. Journal of Coastal Research, Special Issue 36, 164-172. 
Cooper, J.A.G., Pilkey, O.H. 2004a. Sea level rise and shoreline retreat: time to abandon the Bruun Rule. Global and Planetary Change, 43, 157-171.

Cooper, J.A.G., Pilkey, O.H. 2004b. Longshore drift: trapped in an expected universe? Jour. Sediment. Petrol., 74, 599-606.

Cooper, J.A.G., Pilkey, O.H., Lewis, D., 2007. Fetch-limited barrier islands a new coastal landform category. GSA Today 17, 4-9.

Costas, S., Alejo, I., Rial, F., Lorenzo, H., Nombela, M.A. 2006. Cyclical evolution of a modern transgressive sand barrier in Northwestern Spain elucidated by GPR and aerial photos. Jour. Sediment. Res., 76, 1077-1092.

Costas, S., Ferreira, O., Plomaritis, T.A., Leori, E. 2016. Coastal barrier stratigraphy for Holocene high-resolution sea-level reconstruction. Sci. Rep. 6, 38726; doi: $10.1038 /$ srep38726.

Cowell, P.J., Kinsella, M.A. 2018. Shoreface Controls on Barrier Evolution and Shoreline Change. In: Moore, L.J., Murray, A.B. (eds) Barrier dynamics and response to changing climate. Springer, 243-275.

Cowell, P.J., Roy, P.S., Jones, R.A., 1992. Shoreface translation model: computer simulation of coastal-sand-body response to sea level rise. Mathematics and Computers in Simulation, 33, 603-608.

Cowell, P.J., Roy, P.S., Jones, R.A. 1995. Simulation of large-scale coastal change using a morphological behaviour model. Marine Geology, 126, 45-61.

Cowell, P.J., Stive, M.J.F., Niedoroda, A.W., Swift, D.J.P., De Vriend, H.J., Buijsman, M.C., Nicholls, R.J., Roy, P.S., Kaminsky, G.M., Cleveringa, J., Reed, C.W., De Boer, P.L., 2003. The coastal-tract (part 2): applications of aggregated modelling to lower-order coastal change. Journal of Coastal Research 19, 828-848. 
Davies, J.L. 1980. Geographic Variation in Coastal Development. New York: Longman.

Davis, R.A., JR., 1994. Barrier island systems - a geologic overview, In: Davis, R.A. Jr., ed., Geology of Holocene Barrier Island Systems. Berlin, Springer-Verlag, p. 146.

Dawson, A.G., Dawson, S., Cooper, J.A.G., Gemmell, A., Bates, R. 2013. A Pliocene age and origin for the strandflat of the Western Isles of Scotland: a speculative hypothesis. Geological Magazine, 150, 360-366.

Dean, R.G., Maurmeyer, E.M., 1983. Models for beach profile responses. In: Komar, P.D. (Ed.), Handbook of Coastal Processes and Erosion. CRC Press, Boca Raton, Florida, pp. 151- 166.

De Falco, G., Antonioli, F., Fontolan, G., Lo Presti, V., Simeone, S., Tonielli, R. 2015. Early cementation and accommodation space dictate the evolution of an overstepping barrier system during the Holocene. Mar. Geol., 369, 52-66.

de Vriend, H. J. 1991. Mathematical modelling and large-scale coastal behaviour, J. Hydraul. Res., 29, 727-740.

Demarest, J.M., Leatherman, S.P. 1985. Mainland influence on coastal transgression: Delmarva Peninsula. Marine Geology, 63, 19-33.

Devoy, R.J.N. 2015. The development and management of the Dingle Bay SpitBarriers of southwest Ireland. In: Randazzo, G., Jackson, D.W.T. and Cooper, J.A.G. (eds) Sand and Gravel Spits, Springer, Amsterdam, 139-180.

Dillenberg, S.R., Hesp, P.A. (eds) 2009. Geology and geomorphology of Holocene coastal barriers of Brazil. Lecture Notes in Earth Science, 107, Springer, Berlin. 379 pp. 
Dillenberg, S.R., Tomazelli, L.J., Barboza, E.G., 2004. Barrier evolution and placer formation at Bujuru southern Brazil. Mar. Geol. 203, 43-56.

Dolan, R, Godfrey, P. 1973. Effects of Hurricane Ginger on the barrier islands of North Carolina. Geological Society of America Bulletin, 84, 1329-1334.

Donnelly, J.P., Bryant, S.S., Butler, J., Dowling, J., Fan, L., Hausmann, N., Newby, P., Shuman, B., Stern, J., Westover, K., Web, T. 2001. 700 yr sedimentary record of intense hurricane landfalls in southern New England. Geological Society of America Bulletin, 113, 714-727.

Duffy, W., Belknap, D. F., Kelley, J. T. 1989, Morphology and stratigraphy of small barrier-lagoon systems in Maine: Marine Geology, 88, 243-262.

Elias, E.P.L., Van der Spek A.J.F. 2006. Long-term morphodynamic evolution of Texel Inlet and its ebb-tidal delta (The Netherlands). Marine Geology, 225, 5-21.

Evans G., Murray J.W., Biggs H.E.J., Bate R., Bush, P.R., 1973. The oceanography, ecology, sedimentology and geomorphology of parts of the Trucial Coast barrier island complex, Persian Gulf. In: Purser, B.H. (ed) The Persian Gulf. Holocene carbonate sedimentation and diagenesis in a shallow epicontinental sea. Springer, Berlin Heidelberg New York, pp 234-269.

Fagherazzi, S., Overeem, I. 2007. Models of Deltaic and Inner Continental Shelf Landform Evolution. Annual Review of Earth and Planetary Sciences, 35, 685-715.

Fenster, M. S., Dolan, R., Smith, J. J. 2016. Grain-size distributions and coastal morphodynamics along the southern Maryland and Virginia barrier islands. Sedimentology, 63, 809-823.

Ferreira, O., Matias, A., Pacheco, A., 2016. The east coast of Algarve: a barrier island dominated system. Thalassas, 32, 75-85. 
FitzGerald, D.M. 2015. Geologic controls on tidal inlets. Shore and Beach, 83, 5964.

FitzGerald D.M., Buynevich I.V., Argow BA. 2006. Model of tidal inlet and barrier island dynamics in a regime of accelerated sea-level rise. J. Coast. Res. 39, 789-95

FitzGerald, D.M., Fenster, M.S., Argow, B.A. Buynevich, I.V. 2008. Coastal impacts due to sea-level rise. Annual Review of Earth and Planetary Science, 36, 601-647.

FitzGerald, D.M., Hein, C.J., Hughes, Z., Kulp, M., Georgiou, I., Miner, M. 2018. Runaway barrier island transgression concept: global case studies. In: Moore, L.A. and Murray, A.B (eds.) Barrier Dynamics and Response to Changing Climate. Springer, Cham, Switzerland, 3-56.

Flemming, B.W., Davis, R.A. 1994. Holocene evolution, morphodynamics and sedimentology of the Spiekeroog barrier island system, (Southern North Sea). Senckenbergiana maritima, 24, 117-155.

Fontolan, G., Pillon, S., Bezzi, A., Villalta, R., Lipizer, M., Triches A., D'Aietti A. 2012. Human impact and the historical transformation of saltmarshes in the Marano and Grado Lagoon, northern Adriatic Sea. Estuarine Coastal Shelf Sci., 113, 41-56.

Forbes, D. L., Taylor, R.B., Orford, J.D., Carter, R.W.G., Shaw, J. 1991, Gravelbarrier migration and overstepping. Mar. Geol., 97, 305-313.

French, J., Payo, A., Murray, B., Orford, J., Eliot, M., Cowell, P. 2016a. Appropriate complexity for the prediction of coastal and estuarine geomorphic behaviour at decadal to centennial scales. Geomorphology, 256, 3-16.

French, J.R. Burningham, H., Thornhill, G., Whitehouse, R., Nicholls, R.S. 2016 b. Conceptualizing and mapping coupled estuary, coast and inner shelf sediment systems. Geomorphology, 256, 17-35. 
Fruergaard, M., Andersen, T.J., Johannessen, P.N., Nielsen, L.H., Pejrup, M. 2013. Major coastal impact induced by a 1000-year storm event. Sci. Rep., 3,1-7.

Fruergaard, M., Andersen, T.J., Nielsen, L.H., Johannessen, P.N., Aagaard T., Pejrup, M. 2015. High-resolution reconstruction of a coastal barrier system: impact of Holocene sea-level change. Sedimentology, 62, 928-969.

Gardner, J.V., Dartnell, P., Mayer, L.A., Hughes Clarke, J.E., Calder, B.R., Duffy, G. 2005. Shelf-edge deltas and drowned barrier-island complexes on the northwest Florida outer continental shelf. Geomorphology, 64, 133-166.

Gardner, J.V., Calder, B.R., Hughes Clarke, J.E., Mayer, L.A., Elston, G., Rzhanov, Y. 2007. Drowned shelf-edge deltas, barrier islands and related features along the outer continental shelf north of the head of De Soto Canyon, NE Gulf of Mexico. Geomorphology, 89, 370-390.

Godfrey, P.J., Godfrey, M.M., 1973. Comparison of ecological and geomorphic interactions between altered and unaltered barrier island systems in North Carolina. In: Coates, D.R. (Ed.), Coastal Geomorphology. State Univ. New York, New York, pp.239-258.

Gomes, M., Humphries, M., Kirsten, K.L., Green, A.N., Finch, J.M., De Lecea, A.M. 2017. Diatom-inferred hydrological changes and Holocene geomorphic transitioning of Africa's largest estuarine system, Lake St Lucia. Estuarine, Coastal and Shelf Science, 192, 170-180.

Green, A.N., Cooper, J.A.G., Leuci, R., Thackeray, Z. 2013a. Formation and preservation of an overstepped segmented lagoon complex on a high-energy continental shelf. Sedimentology, 60, 1755-1768.

Green, A., Cooper, J.A.G., Le Vieux, A., 2013b. Unusual barrier/inlet behaviour associated with active coastal progradation and river-dominated estuaries. Journal of Coastal Research, Special Issue 69, 35-45. 
Green, A.N, Cooper, J.A.G. Salzmann, L. 2014. Geomorphic and stratigraphic signals of postglacial meltwater pulses on continental shelves. Geology, 42, 151-154.

Green, A.N, Cooper, J.A.G. Salzmann, L. 2018. The role of shelf morphology and antecedent setting in the preservation of palaeo-shoreline (beachrock and aeolianite) sequences: the SE African shelf. Geo-Mar Lett. 38, 5-18.

Gutierrez, B.T., Plant, N.G., Thieler, E.R., 2011. A Bayesian network to predict coastal vulnerability to sea level rise. Journal of Geophysical Research 116, F02009, doi:10.1029/2010JF001891.

Gutierrez, B.T., Plant, N.G., Thieler, E.R., Turecek, A. 2015. Using a Bayesian network to predict barrier island geomorphologic characteristics. J. Geophys. Res. Earth Surf., 120,2452-2475.

Hapke, C.J., Lentz E.E., Gayes, P.T. McCoy, C.A. Hehre R.E., Schwab W.C., Williams, S.J. 2010. A review of sediment budget imbalances along Fire Island, New York: can nearshore geologic framework and patterns of shoreline change explain the deficit? J. Coast. Res., 26, 510-522.

Hapke C.J., Plant N.G., Henderson R.E., Schwab W.C., Nelson T.R. 2016 Decoupling processes and scales of shoreline morphodynamics. Marine Geology, 381, 42-53.

Hayes, M.O. 1979. Barrier island morphology as a function of tidal and wave regime. In: Leatherman, SP (ed.), Barrier Islands: from the Gulf of St. Lawrence to the Gulf of Mexico. New York, Academic Press, 1-28.

Hartstein, N.D., Dickinson, W.W. 2000. Gravel barrier migration and overstepping in Cable Bay, Nelson, New Zealand. Journal of Coastal Research Special Issue 34, 256266.

Hein, C.J., FitzGerald, D.M., deMenezes, J.T., Cleary,W.J., Klein, A.H.F., Albernaz, M.B. 2014. Sedimentological signatures of the mid-Holocene highstand in Brazil. Geol. Soc. Am. Bull., 126, 459-480. 
Hein, C.J., FitzGerald, D.M., de Souza, L.H.P., Georgiou, I.Y., Klein, A.H.F., Buynevich, I.V., Menezes, J.T., Scolaro, T., Cleary, W.J., 2016. Complex coastal change in response to autogenic basin infilling: an example from a sub-tropical Holocene strandplain. Sedimentology, 63, 1362-1395.

Hijma, M.P., van der Spek, A.J.F., van Heteren, S. 2010. Development of a midHolocene estuarine basin, Rhine-Meuse mouth area, offshore The Netherlands. Marine Geology 271, 198-211.

Honeycutt, M.G., Krantz, D.E. 2003. Influence of the geologic framework on spatial variability in long-term shoreline change, Cape Henlopen to Rehoboth Beach, Delaware. J. Coastal Res., 38, 147 - 167.

Hosier, P.E., Cleary, W.J. 1977. Cyclic Geomorphic Patterns of Washover on a Barrier Island in Southeastern North Carolina. Environmental Geology, 2, 23-31

Houser C. 2012. Feedback between ridge and swale bathymetry and barrier island storm response and transgression. Geomorphology, 173, 1-16.

Houser, C. 2013. Alongshore variation in the morphology of coastal dunes: implications for storm response. Geomorphology, 199, 48-61.

Houser C., Hapke, C., Hamilton, S. 2008. Controls on coastal dune morphology, shoreline erosion and barrier island response to extreme storms. Geomorphology, 100, 223-240.

Houser, C., Bishop, M., Wernette, P. 2017. Multi-scale topographic anisotropy patterns on a barrier island. Geomorphology 297, 153-158.

Humphries, M.S., Green, A.N., Finch, J.M. 2016. Evidence of El Nino driven desiccation cycles in a shallow estuarine lake: The evolution and fate of Africa's largest estuarine system, Lake St Lucia. Global and Planetary Change, 147, 97-105. 
Jarrett, B.D., Hine, A.C., Halley, R.B., Naar D.F., Locker, S.D., Neumann, A.C., Twichell, D., Hu, C., Donahue, B.T., Jaap, W.C., Palandro, D., Ciembronowicz, K. 2005. Strange bedfellows - a deep-water hermatypic coral reef superimposed on a drowned barrier island; southern Pulley Ridge, SW Florida platform margin. Mar. Geol. 214, 295-307.

Jennings, S.C., Orford, J.D., Canti, M., Devoy, R.J.N., Straker, V. 1998. The role of relative sea-level rise and changing sediment supply on Holocene gravel barrier development; the example of Porlock, Somerset, UK. The Holocene 8, $165-181$.

Jimenez, J.A. and Sanchez-Arcilla, A. 2004. A long-term (decadal scale) evolution model for microtidal barrier systems. Coastal Engineering Journal, 51, 749-764.

Kana, T.W. 1995. A mesoscale sediment budget for Long Island, New York. Marine Geology, 126, 87-110.

Kahn, J.H., Roberts, H.H. 1982. Variations in storm response along a microtidal transgressive barrier-island arc. Sedimentary Geology 33, 129-146

Kirk R.M., Lauder G.A., 2000. Significant coastal lagoon systems in the South Island, New Zealand: Coastal processes and lagoon mouth closure. Science for Conservation, 146. N.Z. Dept of Conservation, Wellington.

Koster, K., Stafleu, J., Cohen, K. M. 2017. Generic 3D interpolation of Holocene base-level rise and provision of accommodation space, developed for the Netherlands coastal plain and infilled palaeovalleys. Basin Res, 29: 775-797

Kroon, A., Larson, M., Möller, I., Yokoki, H., Rozynski, G., Cox, J., Larroude, P., 2008. Statistical analysis of coastal morphological data sets over seasonal to decadal time scales. Coastal Engineering, 55, 581-600.

Larson, M., Palalane, J., Fredriksson, C., Hanson, H. 2016. Simulating cross-shore material exchange at decadal scale. Theory and model component validation. Coastal Engineering, 116, 57-66. 
Lazarus, E.D., Ellis, M.A., Murray A.B., Hall, D.M. 2015. An evolving research agenda for human-coastal systems. Geomorphology, 256, 81-90.

Leatherman, S.P. (ed), 1979, Barrier Islands from the Gulf of St. Lawrence to the Gulf of Mexico, Academic Press, New York, 325 pp.

Leatherman, S.P., 1983. Barrier dynamics and landward migration with Holocene sealevel rise. Nature, 301, p.415.

Lentz, E.E. Hapke C. 2011. Geologic framework influences on the geomorphology of an anthropogenically modified barrier island: assessment of dune/beach changes at Fire Island, New York. Geomorphology, 126 82-96.

Lentz, E.E. Hapke, C.J. Stockdon, H.F. Hehre R.E. 2013. Improving understanding of near-term barrier island evolution through multi-decadal assessment of morphologic change Mar. Geol., 337. 125-139.

Lesser, G.R., Roelvink, J.A., van Kester, J.A.T.M., Stelling, G.S. 2004. Development and validation of a three-dimensional morphological model. Coast. Eng. 51, 883-915.

List, J., Sallenger Jr., A., Hansen, M., Jaffe, B., 1997. Accelerated relative sea-level rise and rapid coastal erosion: testing a causal relationship for the Louisiana barrier islands. Mar. Geol. 140, 347-365.

Lopes, R.P. Buchmann, F.S. 2011. Pleistocene mammals from the southern Brazilian continental shelf. Journal of South American Earth Sciences, 31, 17-27

Lorenzo-Trueba, J., Ashton A.D. 2014. Rollover, drowning, and discontinuous retreat: Distinct modes of barrier response to sea-level rise arising from a simple morphodynamic model. J. Geophys. Res. Earth Surf., 119, 779-801.

Mallinson, D.J., Culver, S.J., Riggs, S.R., Thieler, E.R., Foster, D., Wehmiller, J., Farrell, K.M., Pierson, J., 2010. Regional seismic stratigraphy and controls on the 
Quaternary evolution of the Cape Hatteras region of the Atlantic passive margin, USA. Mar. Geol. 268, 16-33.

Masselink, G. van Heteren, S. 2014. Response of wave-dominated and mixed-energy barriers to storms. Marine Geology, 352, 321-347.

Masetti, R., Fagherazzi, S., Montanari, A. 2008. Application of barrier island translation model to the millennial-scale evolution of Sand Key, Florida. Cont. Shelf Res., 28, 1116- 1126.

Matias, A., Carrasco, A.R., Loureiro, C., Almeida, S., Ferreira, Ó., 2014. Nearshore and foreshore influence on overwash of a barrier Island. Journal of Coastal Research, S.I. $70,675-680$.

Matias, A., Ferreira, Ó., Vila-Concejo, A., Garcia, T., Dias, J.A., 2008. Classification of washover Dynamics in barrier islands. Geomorphology, 97, 655-674.

Mauz, B., Vacchi, M., Hoffman, G., Green, A., Cooper, J.A.G. 2015. Beachrock: a tool for reconstructing relative sea level in the far-field. Marine Geology, 362, 1-16.

May, S. M., Vött, A., Brückner, H., Grapmayer, R., Handl, M., Wennrich, V. 2012. The Lefkada barrier and beachrock system (NW Greece)- controls on coastal evolution and the significance of extreme wave events. Geomorphology, 139-140, $330-347$.

McBride, R.A., Anderson, J., Buynevich, I.V., Cleary, W.J., Fenster, M.S., FitzGerald, D.M., Harris, M.S., Hein, C.J., Klein, A.H.F., Liu, B., Menezes, J.T., Pejrup, M., Riggs, S.R., Short, A.D., Stone, G.W., Wallace, D.J., Wang, P. 2013. Morphodynamics of barrier systems: a synthesis. In: Shroder, J., Sherman, D.J. (Eds.), Treatise on Geomorphology (Coastal and Submarine Geomorphology), 1st Ed., Academic Press, San Diego, pp. 174-244. 
McBride, R.A., Byrnes, M.R. 1997. Regional variations in shore response along barrier island systems of the Mississippi River delta plain: historical change and future prediction. Journal of Coastal Research, 13, 628-655.

McBride, R.A., Byrnes, M.R., Hiland, M.W. 1995. Geomorphic response-type model for barrier coastlines: a regional perspective. Marine Geology, 126, 143-159.

McMaster, R.L. Garrison L.E. 1967 A submerged Holocene shoreline near Block Island, Rhode Island. J. Geol., 75, 335-340.

McSweeney, S.L., Kennedy, D.M., Rutherfurd, I.D., Stout, J.C., 2017. Intermittently Closed/Open Lakes and Lagoons: Their global distribution and boundary conditions. Geomorphology, 292, 142-152.

Mellet, C.L., Hodgson, D.M., Lang, A., Mauz, B., Selby, I., Plater, A.J., 2012. Preservation of a drowned gravel barrier complex: A landscape evolution study from the north-eastern English Channel. Marine Geology 315-318, 115-131.

Miselis, J.L., McNinch J.E. 2006. Calculating shoreline erosion potential using nearshore stratigraphy and sediment volume: Outer Banks, North Carolina, J. Geophys. Res., 111, F02019, doi:10.1029/2005JF000389.

Moore, L. J., List, J. H. Williams S. J., Stolper, D. 2010, Complexities in barrier island response to sea level rise: Insights from numerical model experiments, North Carolina Outer Banks. J. Geophys. Res., 115, F03004

Moore, L.J. Patsch, K., List, J.H., Williams S.J. 2014. The potential for sea-levelrise-induced barrier island loss: insights from the Chandeleur Islands, Louisiana, USA. Mar. Geol., 355, 244-259.

Morton, R. A. 2007. Historical changes in the Mississippi-Alabama Barrier Islands and the roles of extreme storms, sea level, and human activities, U.S. Geological Survey Open-File Report 2007-1161, 42p. 
Mulhern, J.S., Johnson, C.L., Martin, J.M. 2017. Is barrier island morphology a function of tidal and wave regime? Marine Geology, 387, 74-84.

Murray, A. B. 2003, Contrasting the goals, strategies, and predictions associated with simplified numerical models and detailed simulations. In Iverson R.M. and Wilcock P.R. (eds.) Prediction in Geomorphology, Geophys. Monogr. Ser., vol. 136, pp. 151 165, AGU, Washington, D.C.

Murray, A.B. 2007. Reducing model complexity for explanation and prediction. Geomorphology, 90, 178-191.

Murray, A.B., Moore, L.J. 2018. Geometric Constraints on Long-Term Barrier Migration: From Simple to Surprising. In: Moore, L.J., Murray, A.B. (eds) Barrier dynamics and response to changing climate. Springer, 211-241.

Oertel, G.F., 1985. The barrier island system. Marine Geology, 63, 1-18.

Oliver TS, Tamura T, Hudson JP, Woodroffe CD. 2017 Integrating millennial and interdecadal shoreline changes: Morpho-sedimentary investigation of two prograded barriers in southeastern Australia. Geomorphology, 288, 129-47.

Orford, J.D., Carter, R.W.G., Jennings, S.C. 1991. Coarse clastic barrier environments: evolution and implications for Quaternary sea level interpretations. Quaternary International, 9, 87-104.

Orford, J.D., Carter, R.W.G., McKenna, J., Jennings, S.C. 1995. The relationship between the rate of mesoscale sea-level rise and the retreat rate of swash-aligned gravel-dominated coastal barriers. Mar. Geol. 124, 177 - 186.

Orford, J., Cooper, A., McKenna, J. 1999. Mesoscale temporal changes to foredunes at Inch Spit, south-west Ireland. Zeitschrift fur Geomorphologie, 43, 439-461. 
Orford, J.D., Forbes, D.L., Jennings, S.C. 2002. Organisational controls, typologies and time scales of paraglacial gravel-dominated coastal systems. Geomorphology, $48,51-85$.

Pavlis, T.L., Mason, K.A. 2017. The new world of 3D geologic mapping. GSA Today, 27, doi: 10.1130/GSATG313A.1.

Penland, S., Suter, J.R., Boyd, R. 1985. Barrier island arcs along abandoned Mississippi River deltas. Marine Geology, 63, 197-233.

Pierce, J.W., 1969. Sediment budget along a barrier island chain. Sedimentary Geology, 3, 5-16.

Pilkey, O.H., 2003. A Celebration of the World's Barrier Islands. New York, Columbia University Press, 309pp.

Pilkey, O.H., Cooper, J.A.G. 2004. Society and sea-level rise. Science, 303, 17811782.

Pilkey, O.H., Cooper, J.A.G. 2006. Discussion of Cowell et al., 2006. Management of uncertainty in predicting climate-change impacts on beaches, Journal of Coastal Research 22(1) 232-245. Journal of Coastal Research, 22, 1579-158.

Pilkey, O.H., Cooper, J.A.G. 2014. The Last Beach. Duke University Press 314 pp.

Pilkey, O.H., Cooper, J.A.G., Lewis, D.A., 2009. Global distribution and geomorphology of fetch-limited barrier islands. Journal of Coastal Research, 25, 819837.

Pilkey, O.H., Neal, W.J., Monteiro, J.H., Dias, J.M.A., 1989. Algarve barrier islands: a non coastal plain system in Portugal. Journal of Coastal Research, 5, 239-261. 
Pilkey, O.H., Rice, T., Neal, W. 2004. How to Read a North Carolina Beach, Bubble Holes, Barking Sands, and Rippled Runnels. The University of North Carolina Press, Chapel Hill and London.

Plant, N.G., Robert Thieler, E., Passeri, D.L., 2016. Coupling centennial-scale shoreline change to sea-level rise and coastal morphology in the Gulf of Mexico using a Bayesian network. Earth's Future, 4, 143-158.

Poirier, C., Tessier, B., Chaumillon, E., Bertin, X., Fruergaard, M., Mouazé, D., Noël, S., Weill, P., Wöppelmann, G. 2017. Decadal changes in North Atlantic atmospheric circulation patterns recorded by sand spits since 1800 CE. Geomorphology, 281, 1-12.

Porat, N., Botha, G. A. 2008. The luminescence chronology of dune development on the Maputaland coastal plain, southeast Africa. Quaternary Science Reviews, 27, $1024-1046$.

Preusser, F., Schreurs, G. 2011. Dating sediments in coastal areas and potential applications for constraining the palaeo-environmental context of an archaeological site at Vohemar. Études océan Indien, 46-47. DOI : 10.4000/oceanindien. 1344

Pretorius, L., Green, A.N. Cooper, J.A.G. 2016. Shoreline preservation and ravinement during rapid postglacial sea-level rise and subsequent slowstand. Bulletin of the Geological Society of America. doi: 10.1130/B31381.1

Pretorius, L., Green, A.N.,Cooper, J.A.G. 2018. Submerged beachrock preservation in the context of wave ravinement. Geo-Marine Letters, 38, 19-32.

Priestas, A.M., Fagherazzi S., 2010. Morphological barrier island changes and recovery of dunes after Hurricane Dennis, St. George Island, Florida. Geomorphology, 114, 614-626.

Raji, O., Del Río, L., Gracia, F.J., Benavente, J., 2011. The use of LIDAR data for mapping coastal flooding hazard related to storms in Cádiz Bay (SW Spain). Journal of Coastal Research, 64, 1881-1885. 
Rampino, M.R. Sanders J.E. 1981. Evolution of the barrier islands of southern Long Island, New York, Sedimentology, 28, 37-48.

Rampino, M.R. Sanders J.E. 1982 Holocene transgression in south-central Long Island, New York — reply. J. Sediment. Petrol., 52, 1020-1025

Ranasinghe, R., Swinkels, C. Luijendijk, A., Roelvink, D., Bosboom, J., Stive, M. 2011. Morphodynamic upscaling with the MORFAC approach: Dependencies and sensitivities. Coastal engineering 58, 806-811.

Reeve, D.E., Karunarathna H. 2009. On the prediction of long-term morphodynamic response of estuarine systems to sea level rise and human interference. Cont. Shelf Res., 29, 938-95.

Reeve, D.A., Karunarathna, H., Pan, S., Horrillo-Caraballo, J.M., Różyński, G., Ranasinghe, R. 2016. Data-driven and hybrid coastal morphological prediction methods for mesoscale forecasting. Geomorphology, 256, 49-67.

Reguero, B.G., Menéndez, M., Méndez, F.J., Mínguez, R., Losada I.J. 2012. A Global Ocean Wave (GOW) calibrated reanalysis from 1948 onwards. Coastal Engineering, $65,38-55$.

Reinson, G.E. 1992. Transgressive barrier island and estuarine systems. In: Walker, R.G. (ed.) Facies models: response to sea level change, Geol. Assoc. Can. 179-194.

Rieu, R., Van Heteren, S., Van der Spek, A.J.F., De Boer, P.L. 2005. Development and preservation of a Mid-Holocene tidal-channel network offshore the western Netherlands. Journal of Sedimentary Research, 75, 409-419.

Riggs, S.R. Cleary, W.J. Snyder S.W. 1995. Influence of inherited geologic framework on barrier shoreface morphology and dynamics Mar. Geol., 126, 213234. 
Rink, W.J., Lopez, G.I., 2010. OSL-based lateral progradation and aeolian sediment accumulation rates for the Apalachicola Barrier Island Complex, North Gulf of Mexico, Florida. Geomorphology, 123, 330-342.

Roelvink, J.A. 2006. Coastal morphodynamic evolution techniques. Coastal Engineering, 53, $277-287$.

Rosati, J.D. Dean, R.G., Stone, G.W. 2010.A cross-shore model of barrier island migration over a compressible substrate. Marine Geology, 271, 1-16.

Roy, P.S. Williams, R.J. Jones A.R., Yassin I., Gibbs P.J., Coaters B, West R.J., Scanes P.R, Hudson, J.P., Nichol, S., 2001. Structure and function of south-east Australian estuaries Estuar. Coast. Shelf Sci., 53, 351-384.

Roy, P.S., Cowell, P.J., Ferland, M.A., Thom, B.G. 1994. Wave-dominated coasts. In: Coastal Evolution - Late Quaternary shoreline morphodynamics (Ed. R.W.G. Carter and C.D. Woodroffe), pp. 121-186. University Press, Cambridge.

Ruggiero, P., Kaminsky, G.M., Gelfenbaum, G., Voigt, B. 2005. Seasonal to interannual morphodynamics along a high-energy dissipative littoral cell. Journal of Coastal Research, 21, 553-578.

Ruggiero, P., Kaminsky, G.M., Gelfenbaum, G., Cohn, N. 2016. Morphodynamics of prograding beaches: A synthesis of seasonal-to century-scale observations of the Columbia River littoral cell. Marine Geology, 376, 51-68.

Safak, I., List, J. H., Warner, J. C., Schwab, W. C. 2017. Persistent shoreline shape induced from offshore geologic framework: Effects of shoreface connected ridges. Journal of Geophysical Research: Oceans, 122. doi.org/10.1002/2017JC012808

Sallenger Jr., A. H., 2000. Storm impact scale for barrier islands. Journal of Coastal Research, 16, 890-895. 
Sallenger, A., Krabill, W., Swift, R., Brock, J., 2001. Quantifying hurricane-induced coastal changes using topographic lidar. Proceedings Coastal Dynamics '01, 10071016.

Salzmann, L., Green, A., Cooper, J.A.G., 2013. Submerged barrier shoreline sequences on a high energy, steep and narrow shelf. Marine Geology, 346, 366-374.

Sanders, J.E., Kumar, N., 1975, Evidence of shoreface retreat and in-place "drowning" during Holocene submergence of barriers, shelf off Fire Island, New York: Geol. Soc. America Bull., 86, 65-76.

Schwab, W.C., Thieler, E.R.F., Allen, J.R., Foster, D.S., Swift, B.A., Denny. J.F. 2000. Influence of inner continental shelf geologic framework on the evolution and behaviour of the barrier-island system between Fire Island Inlet and Shinnecock Inlet, Long Island, New York. Journal of Coastal Research 15, 408-422.

Schwab, W.C., Baldwin, W.E., Hapke, C.J., Lentz, E.E., Gayes, P.T., Denny, J.F., List, J.H., Warner, J.C., 2013. Geologic evidence for onshore sediment transport from the inner continental shelf: Fire Island, New York. Journal of Coastal Research 29, $526-544$.

Schwab, W.C., Baldwin, W.E., Warner, J.C., List, J.H., Denny, J.F., Liste, M., Safak, I. 2017. Change in morphology and modern sediment thickness on the inner continental shelf offshore of Fire Island, New York between 2011 and 2014: Analysis of hurricane impact. Marine Geology, 391, 48-64.

Schwartz, R.K., 1975. Nature and Genesis of Some Storm Wash-over Deposits. Technical Memorandum 61. U.S. Army Corps of Engineers, Coastal Engineering Research Center, Ft. Belvoir, Virginia, 99 pp.

Sloss, C.R. Jones, B.G. McClennen, C., de Carli, J., Price, D.M. 2006. The geomorphological evolution of a wave dominated barrier estuary: Burrill Lake, New South Wales, Australia. Sediment. Geol., 187, 229-249. 
Stolper, D., List, J.H., Thieler, E.R. 2005. Simulating the evolution of coastal morphology and stratigraphy with a new morphological-behaviour model (GEOMBEST). Mar. Geol. 218, 17-36.

Stone, G.W., Liu, B., Pepper, D.A., Wang, P. 2004. The importance of extratropical and tropical cyclones on the short-term evolution of barrier islands along the northern Gulf of Mexico, USA. Marine Geology, 210, 63-78.

Storms, J.E.A. 2003. Event-based stratigraphic simulation of wave-dominated shallow-marine environments. Marine Geology, 199, 83-100

Storms, J.E.A., Weltje, G.J., van Dyke, J.J., Geel, C.R., Kroonenberg, S.B. 2002. Process-response modelling of wave-dominated coastal systems: simulating evolution and stratigraphy on geological timescales. Journal of Sedimentary Research 72, $226-$ 239.

Storms, J.E.A., Weltje, G.J., Terra, G.J., Cattaneo, A., Trincardi, F. 2008. Coastal dynamics under conditions of rapid sea-level rise: Late Pleistocene to Early Holocene evolution of barrier-lagoon systems on the northern Adriatic shelf (Italy). Quaternary Science Reviews 27, 1107-1123.

Stutz, M.L., Pilkey, O.H., 2002. Global distribution and morphology of deltaic barrier island systems. Journal of Coastal Research (Special Issue 36), 694-707.

Stutz, M.L. \& Pilkey, O.H. 2011. Open-Ocean Barrier Islands: Global Influence of Climatic, Oceanographic, and Depositional Settings. Journal of Coastal Research, $272,207-222$.

Styles, R., Brown, M.E., Brutsché, K.E., Li, H., Beck, T.M. and Sánchez, A., 2016. Long-Term morphological modeling of barrier island tidal inlets. Journal of Marine Science and Engineering, 4, paper 65, 23pp.

Swift, D.J.P. Moslow, T.F. 1982 Holocene transgression in south-central Long Island, New York — discussion. J. Sediment. Petrol., 52, 1014-1019 
Swift, D.J.P., Niederoda, A.W., Vincent, C.E., Hopkins, T.S. 1985. Barrier island evolution, middle Atlantic shelf, U.S.A. Part I: Shoreface dynamics. Marine Geology, 63, 331-361.

Tamura, T. 2012. Beach ridges and prograded beach deposits as palaeoenvironment records. Earth-Science Reviews, 114, 279-297.

Thieler, E.R., Brill, A.L., Cleary, W.J., Hobbs, C.H., Gammisch, R.A. 1995. Geology of the Wrightsville Beach, North Carolina shoreface: Implications for the concept of shoreface profile of equilibrium. Marine Geology, 126, 271-287.

Thieler, E.R., Pilkey, O.H., Cleary, W.J., Schwab, W.C., 2001. Modern sedimentation on the shoreface and inner continental shelf at Wrightsville Beach, North Carolina, USA. Journal of Sedimentary Research 71, 958-970.

Valvo, L.M.; Murray, A.B., Ashton, A. 2006. How does underlying geology affect coastline change? An initial modelling investigation. Journal of Geophysical Research, 111, F02025

Van Heteren, S., Huntley, D.J., Van de Plassche, O. \& Lubberts, R.K. 2000: Optical dating of dune sand for the study of sea-level change. Geology 28, 411-414.

van Maanen, B., Nicholls, R. J., French, J. R., Barkwith, A., Bonaldo, D., Burningham, H., Murray, A. B., Payo, A., Sutherland, J., Thornhill, G., Townend, I. H., van der Wegen, M., Walkden, M.J.A. 2016. Simulating mesoscale coastal evolution for decadal coastal management: A new framework integrating multiple, complementary modelling approaches, Geomorphology, 256, 68-80.

Villalobos, C.A., Prieto, F.J.G., González, J.B., 2009. Evolución histórica de la línea de costa en el sector meridional de la Bahía de Cádiz. Revista Atlántica-Mediterránea de Prehistoria y Arqueología Social, 11, 13-37. 
Vitousek, S., Barnard, P.L., Limber, P., Erikson, L., Cole, B. 2017. A model integrating longshore and cross-shore processes for predicting long-term shoreline response to climate change. Journal of Geophysical Research: Earth Surface 122, $782-806$.

Vosdoukas, M.I., Velegrakis, A.F., Plomaritis, T.A. 2007. Beachrock occurrence, characteristics, formation mechanisms and impacts. Earth Sci. Rev. 85, 23-46.

Walters, D., Moore, L.J. Duran Vinent, O., Fagherazzi, S., Mariotti, G. 2014, Interactions between barrier islands and backbarrier marshes affect island system response to sea level rise: Insights from a coupled model, J. Geophys. Res. Earth Surf., 119, 2013-2031, doi:10.1002/2014JF003091.

Warner, J.C., Sherwood, C.R., Signell, R.P., Harris, C.K., Arango, H.G. 2008. Development of a three-dimensional, regional, coupled wave, current, and sedimenttransport model. Comput. Geosci. 34, 1284-1306.

Warner, J.C., Armstrong, B., He, R., Zambon, J.B. 2010. Development of a coupled ocean-atmosphere-wave-sediment transport (COAWST) modelling system Ocean Modelling 35, 230-244.

Warrick, J.A., Bountry, J.A., East, A.E., Magirl, C.S., Randle, T.J., Gelfenbaum, G.R., Ritchie, A.C., Pess, G.R., Leung, V., Duda, J.J., 2014. Large-scale dam removal on the Elwha River, Washington, USA: source-to-sink sediment budget and synthesis. Geomorphology, 246, 729-750.

Wernette, P., Houser, C., Weymer, B.A., Everett, M.E., Bishop, M.P., Reece, B. 2018. Influence of a spatially complex framework geology on barrier island geomorphology. Marine Geology, 398, 151-162.

Weymer, B.A., Everett, M.E., de Smet, T.S., Houser, C. 2015. Review of electromagnetic induction for mapping barrier island framework geology. Sedimentary Geology, 321, 11-24. 
White, S.A., Wang, Y. 2003. Utilizing DEMs derived from LIDAR data to analyse morphologic change in the North Carolina coastline. Remote Sensing of Environment 85: 39-47. D

Wolinsky, M. A., Murray A. B. 2009. A unifying framework for shoreline migration: 2. Application to wave-dominated coasts. J. Geophys. Res., 114, F01009.

Wijnberg, K.M. 2002. Environmental controls on decadal morphologic behaviour of the Holland coast. Marine Geology 189, 227-247.

Wijnberg, K.M. Terwindt J.H.J. 1995. Extracting decadal morphologic behaviour from high resolution, long-term bathymetric surveys along the Holland coast using eigenfunction analysis Mar. Geol., 126, 301-330.

Zaremba, N., Mallinson, D.J., Leorri, E., Culver, S., Riggs, S., Mulligan, R., Horsman, E., Mitra, S., 2016. Controls on the stratigraphic framework and paleoenvironmental change within a Holocene estuarine system: Pamlico Sound, North Carolina, USA. Marine Geology, 379, 109-123.

Zhang, W., Harff, J., Schneider, R., Wu, C. 2010. Development of a modelling methodology for simulation of long-term morphological evolution of the southern Baltic coast. Ocean Dynamics, DOI 10.1007/s10236-010-0311-5

Zhang, W., Schneider, R., Harff, J. 2012 A multi-scale hybrid long-term morphodynamic model for wave-dominated coasts Geomorphology, 149-150, 49-61. 

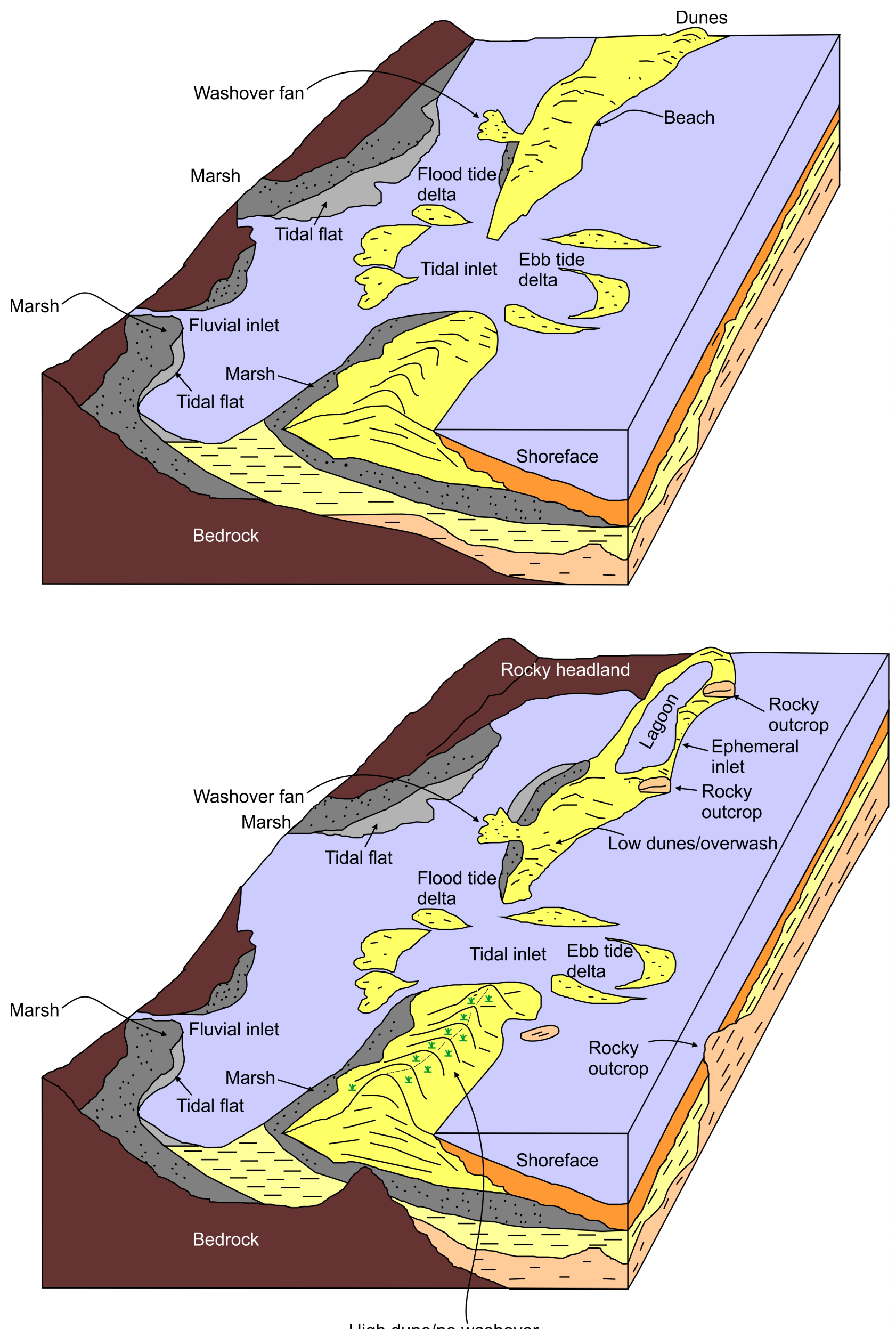

High dune/no washover 

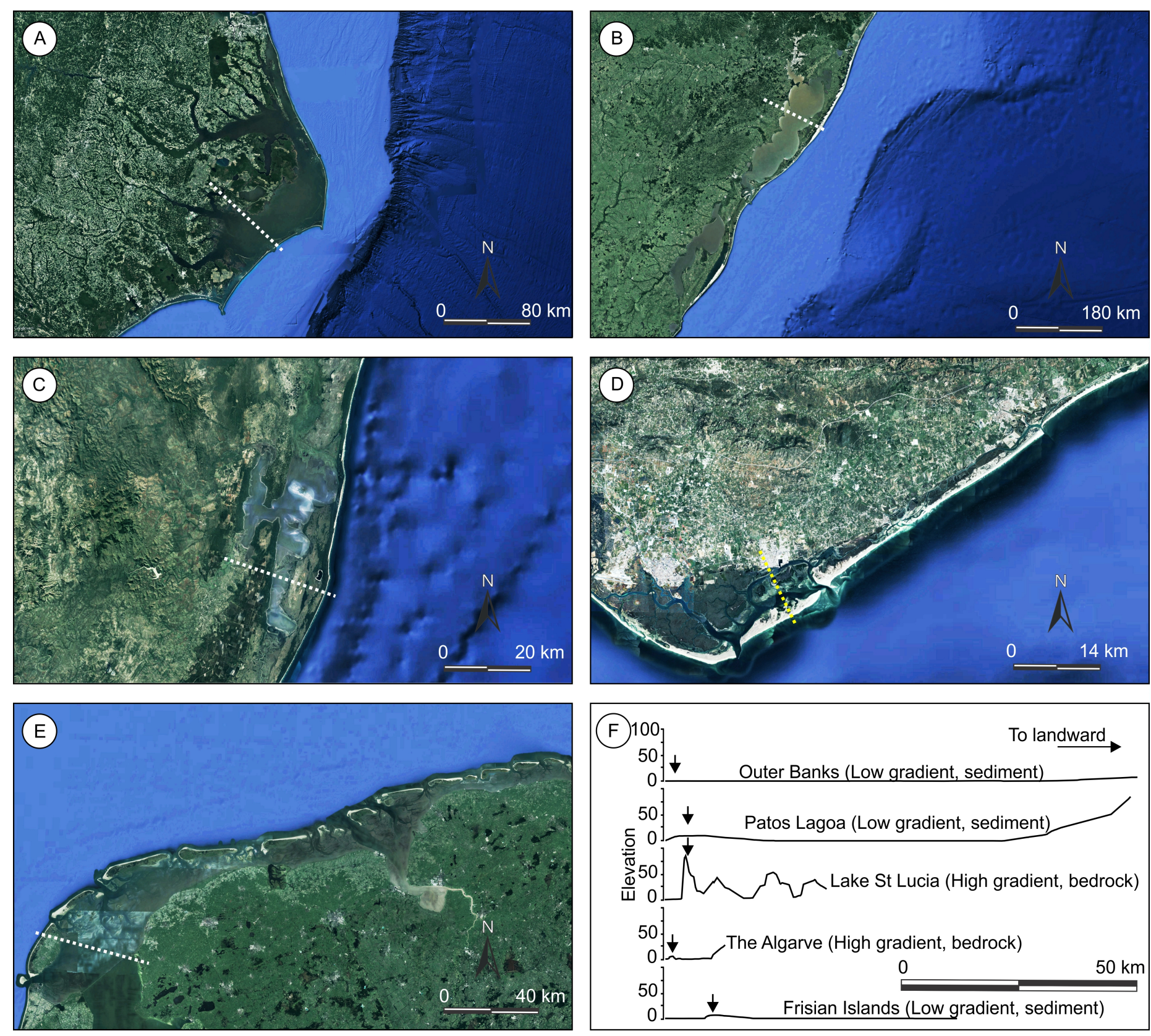


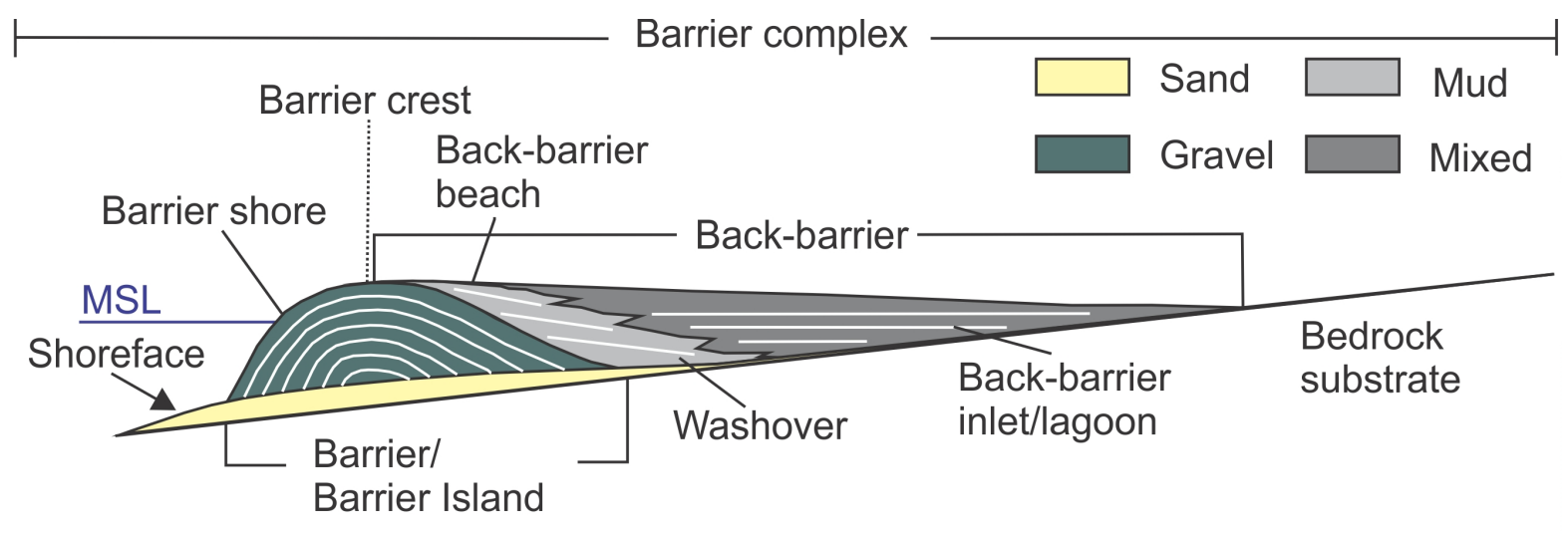

(A) Seaward

Landward

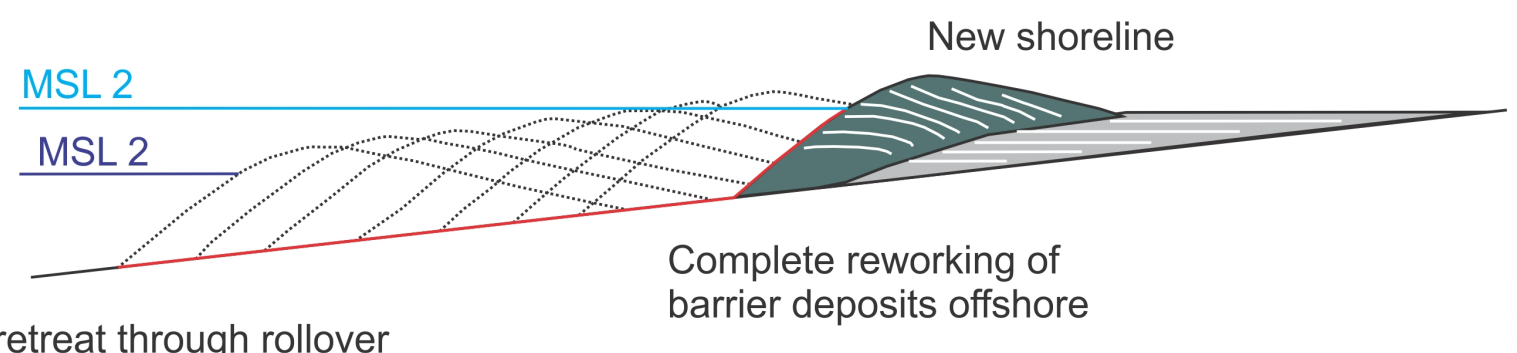

Barrier retreat through rollover

Complete reworking of

(B) Seaward

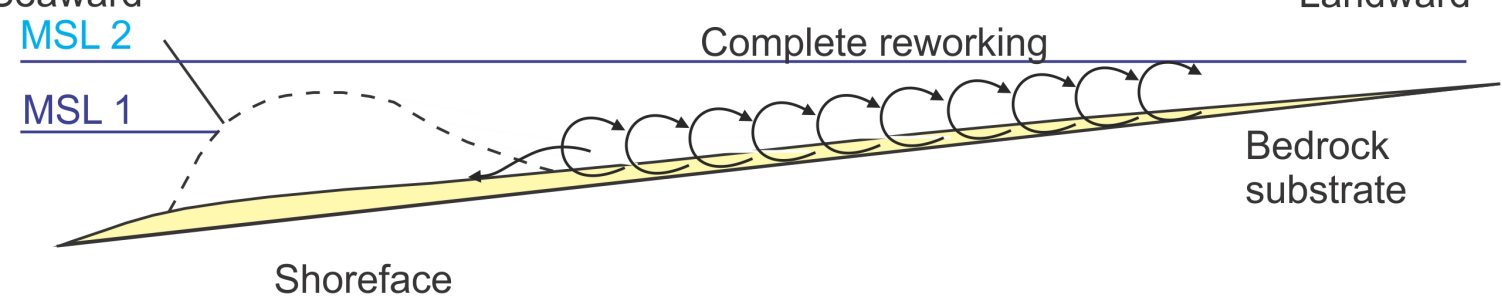

(C) Seaward

Landward

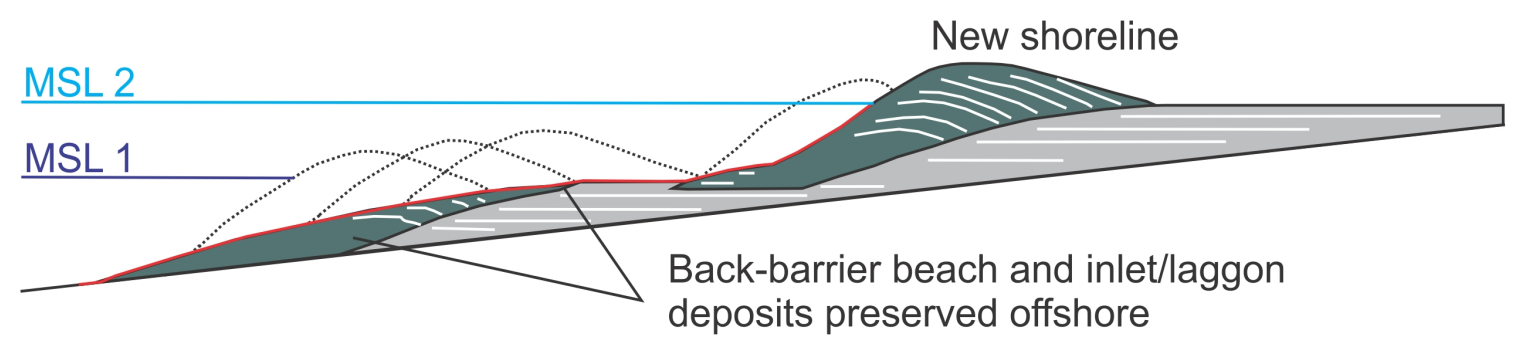

Barrier retreat through overstepping

(D)

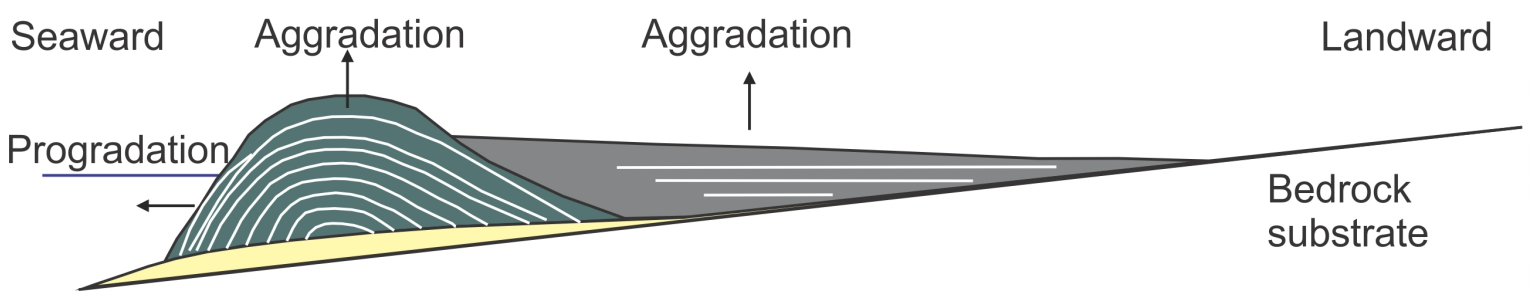




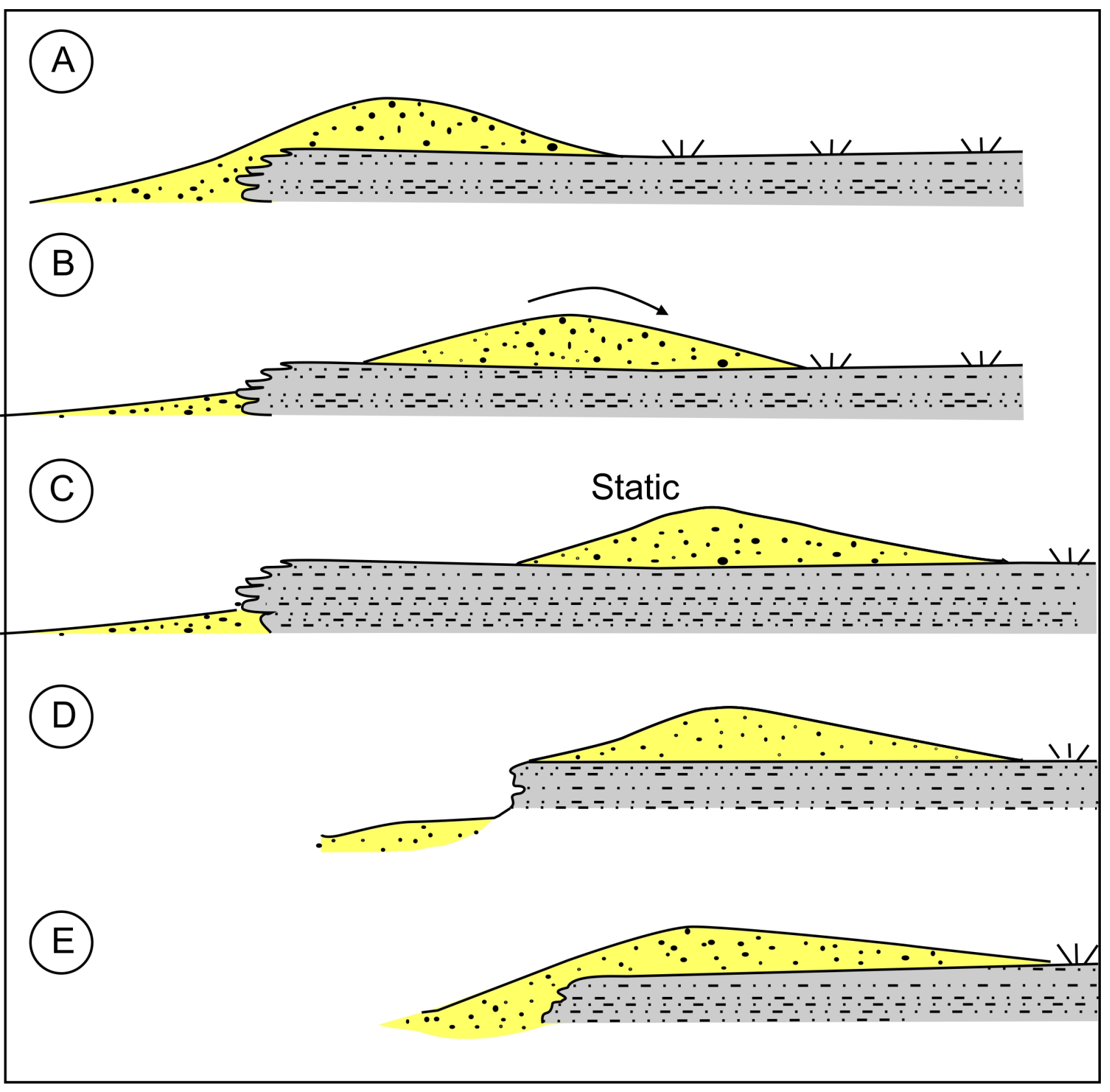



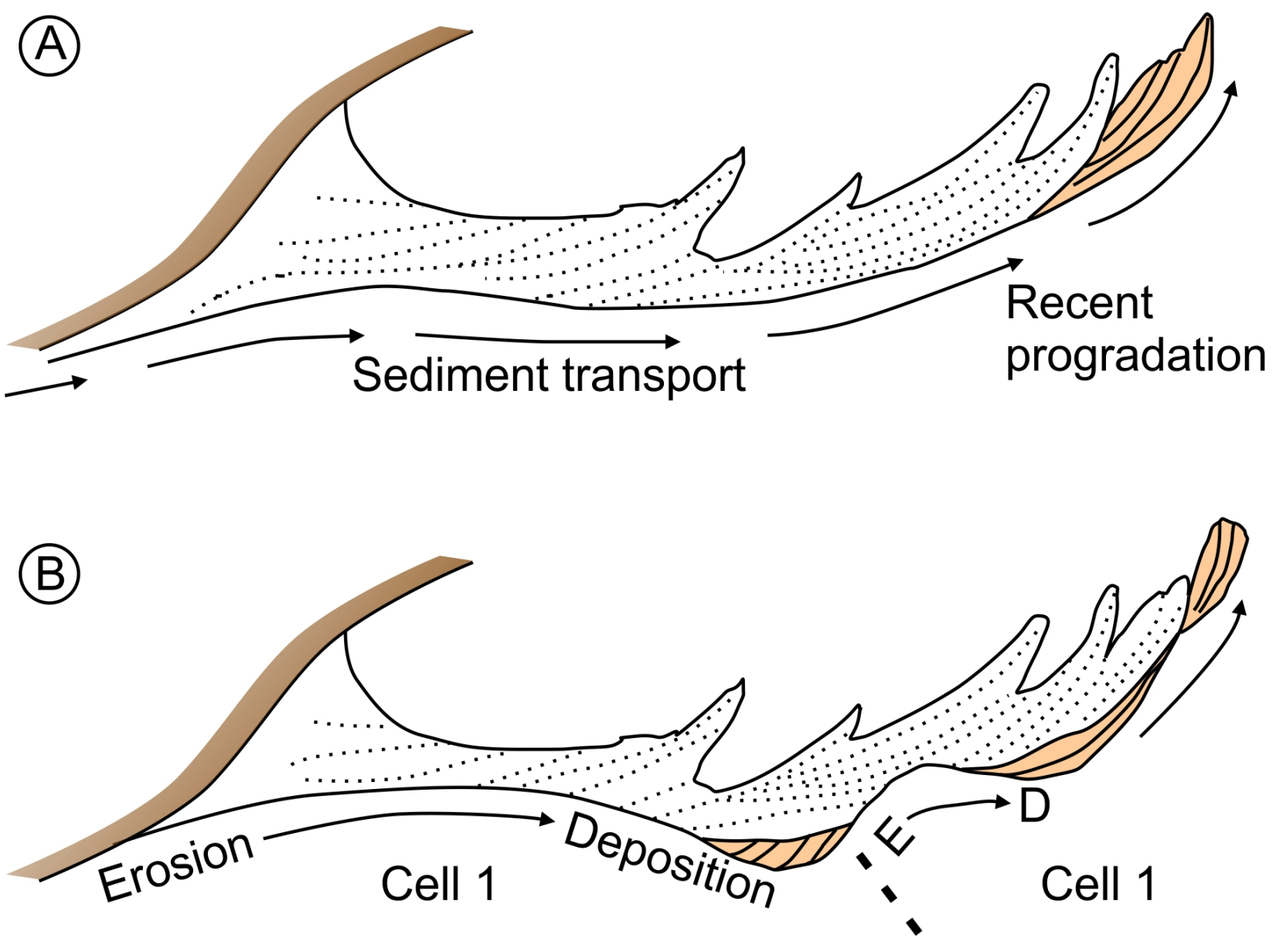

(C)

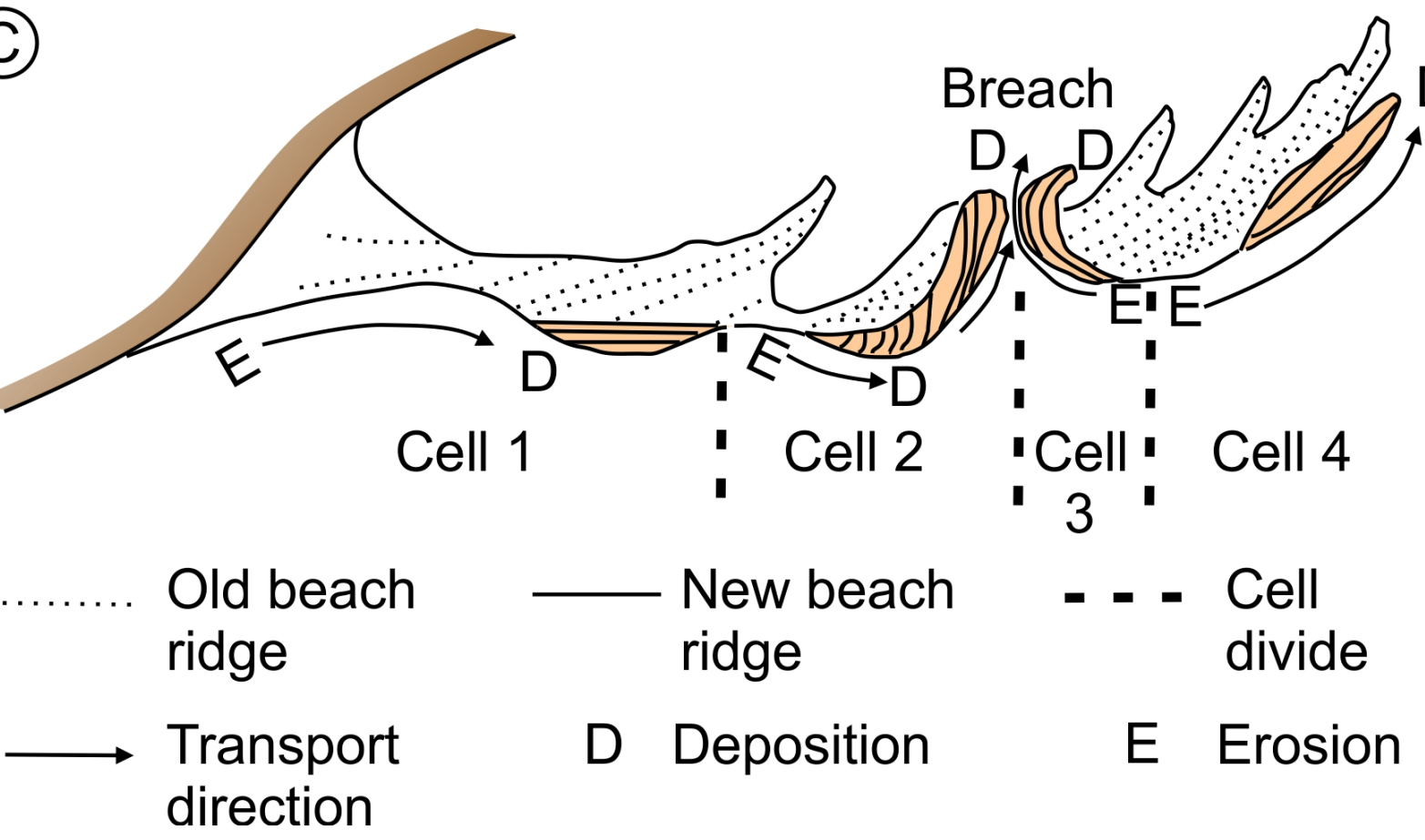




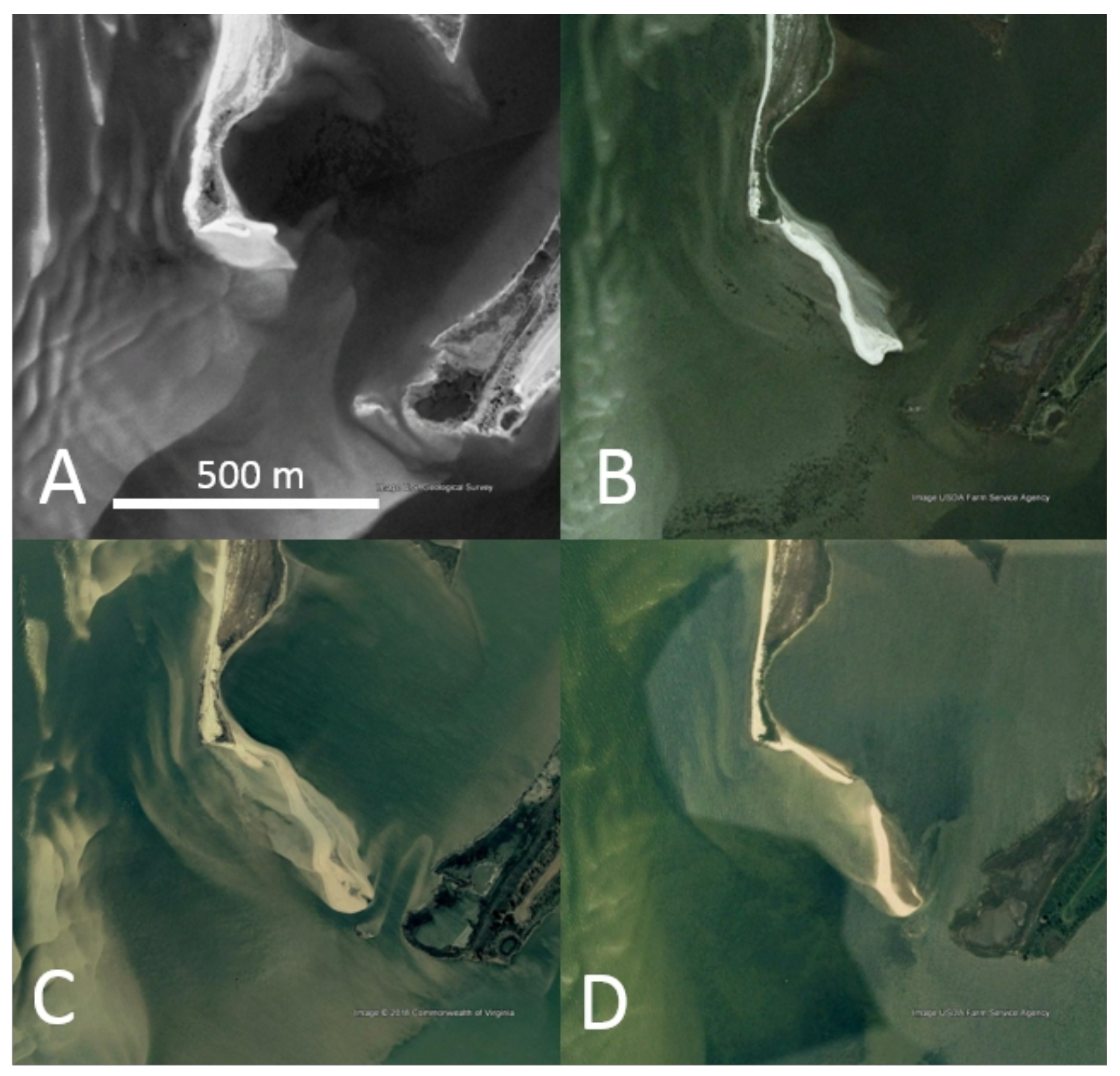




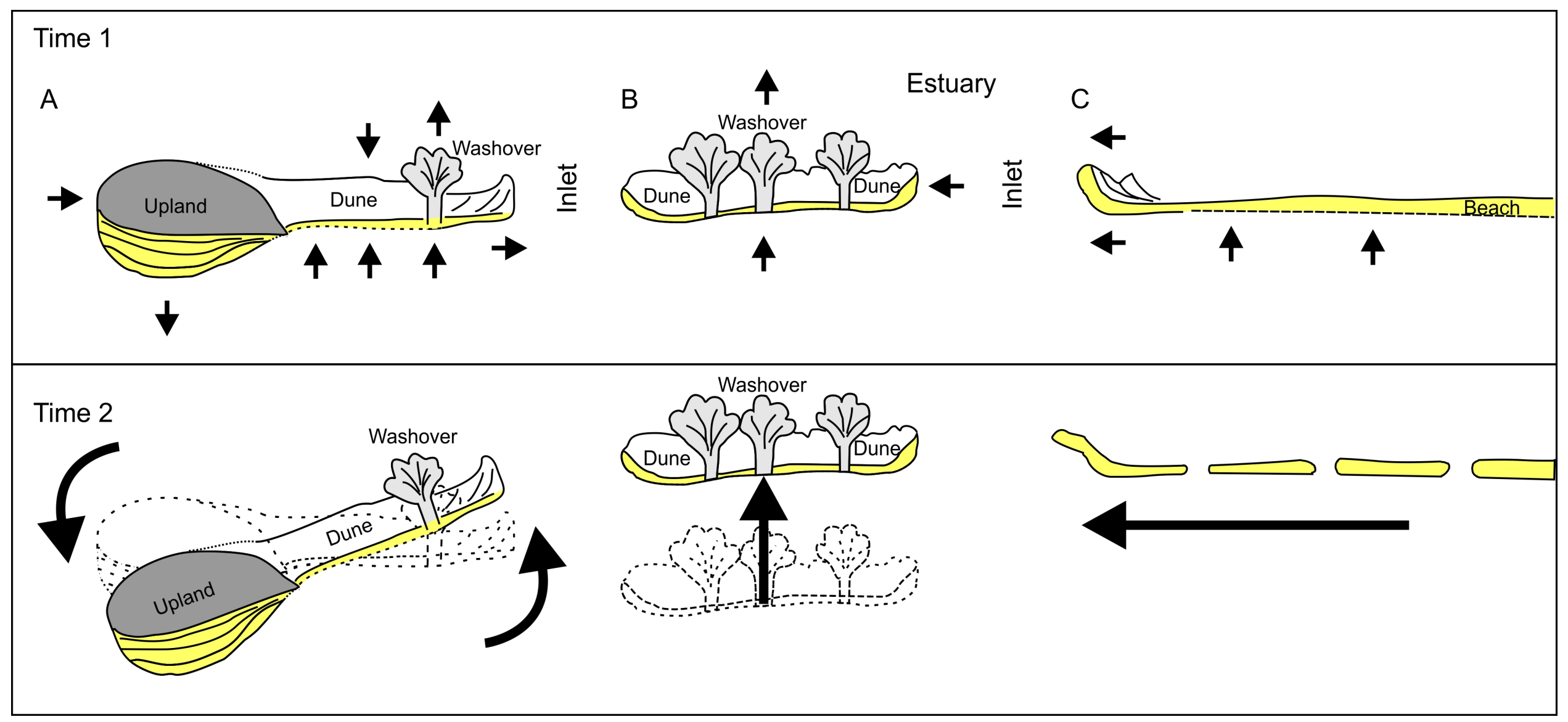




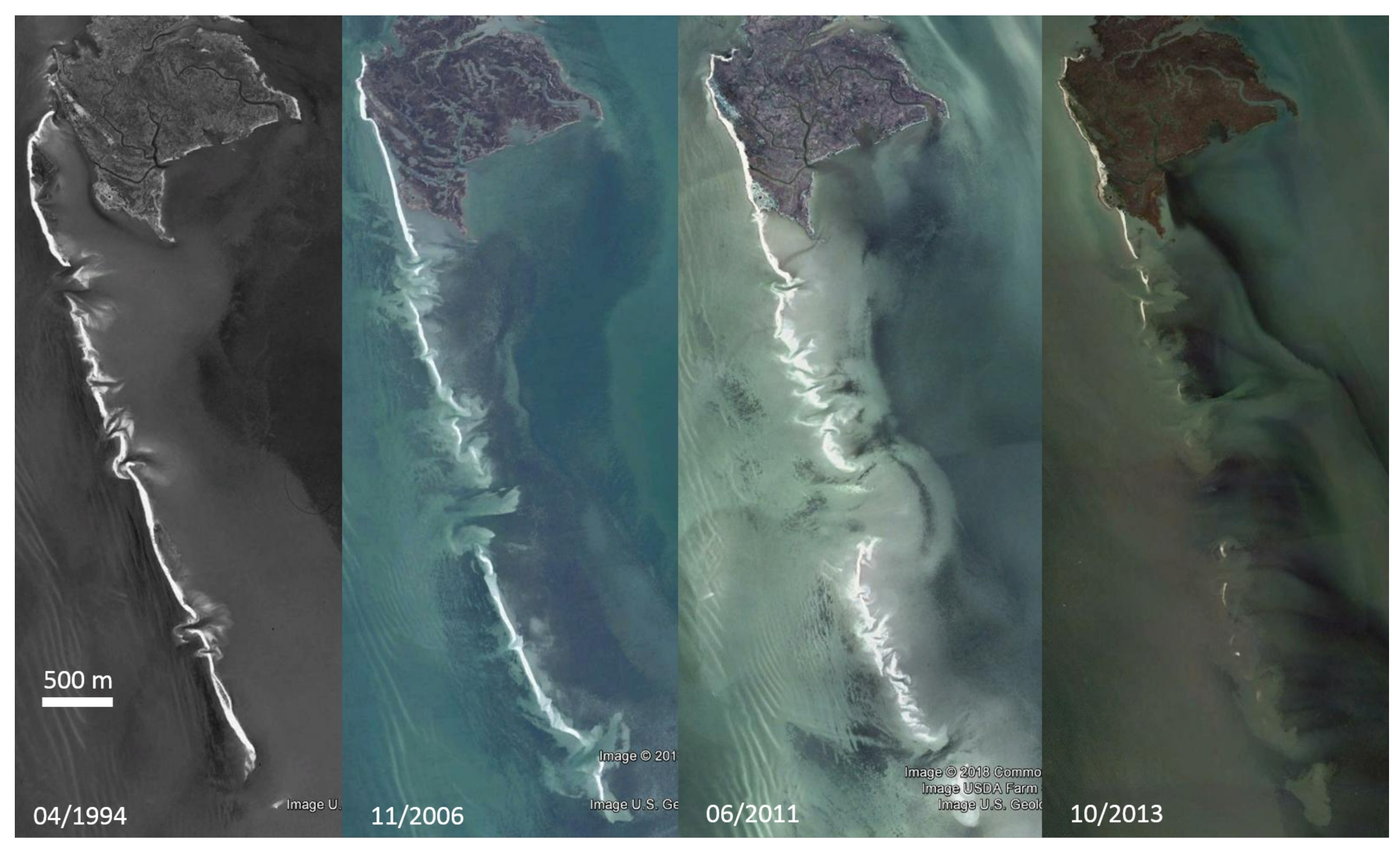



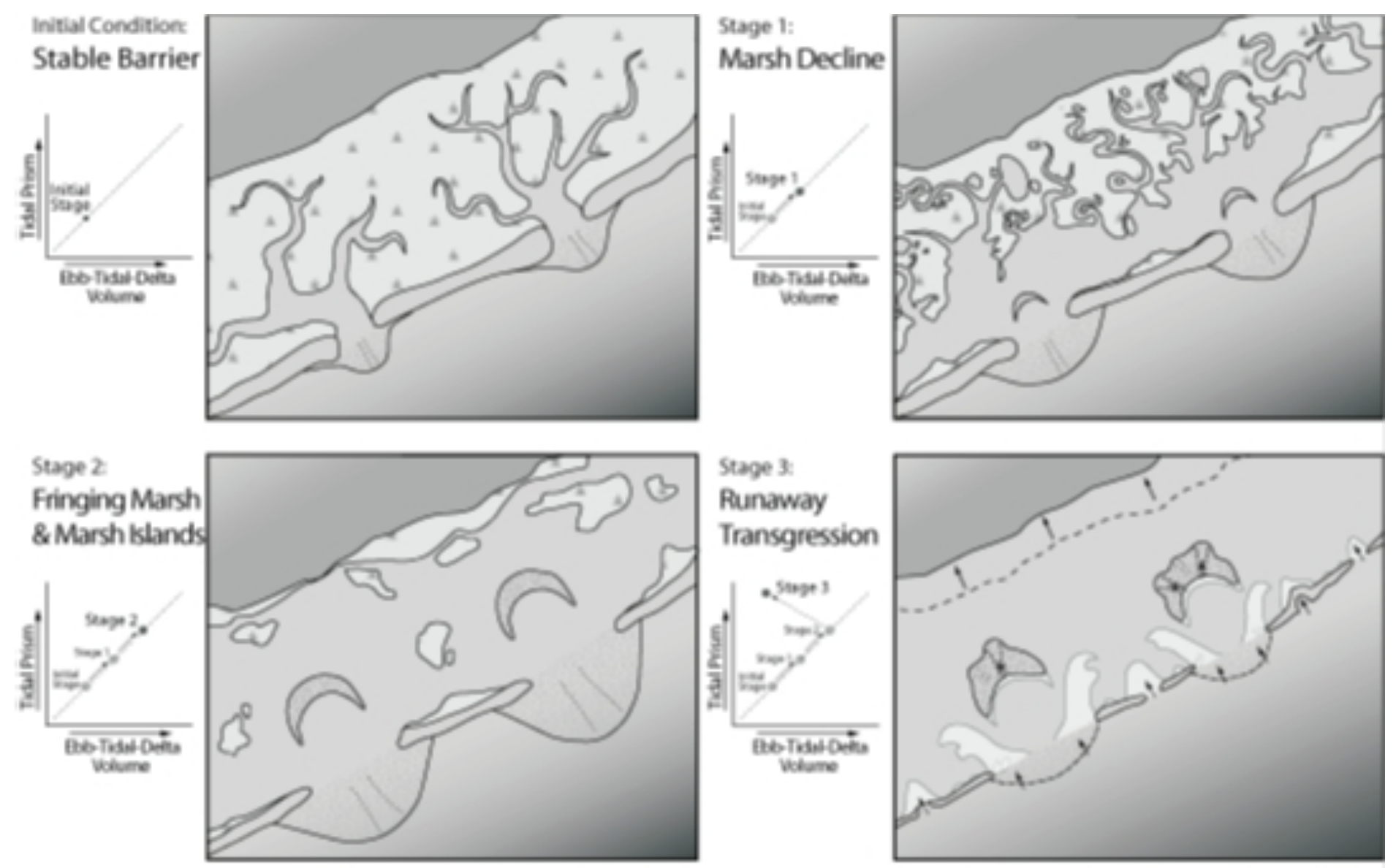


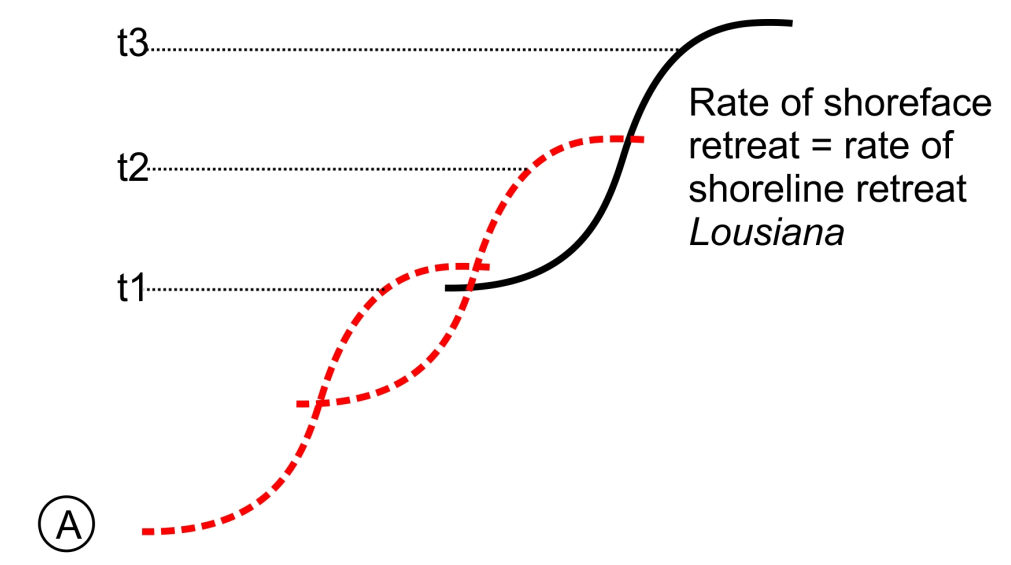

t3.

(B)
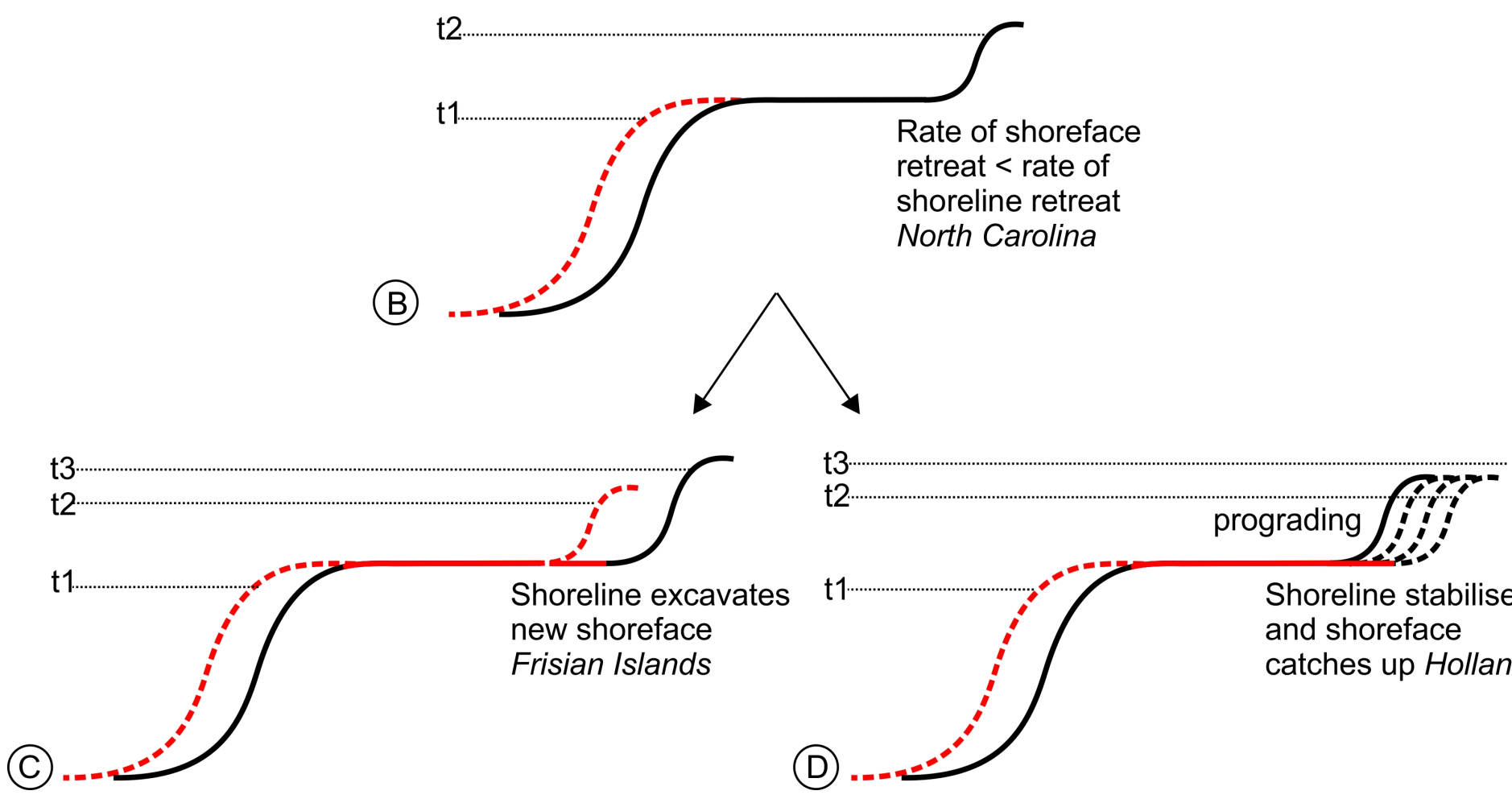

Shoreline excavates

new shoreface

Frisian Islands

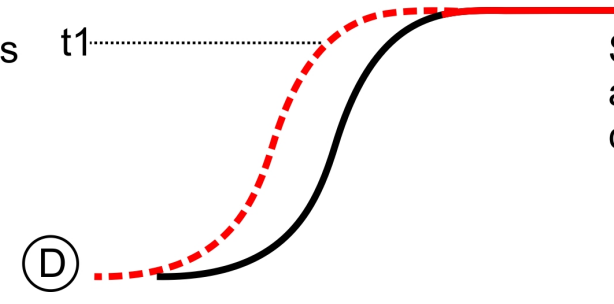

Shoreline stabilises and shoreface

catches up Holland 
a)

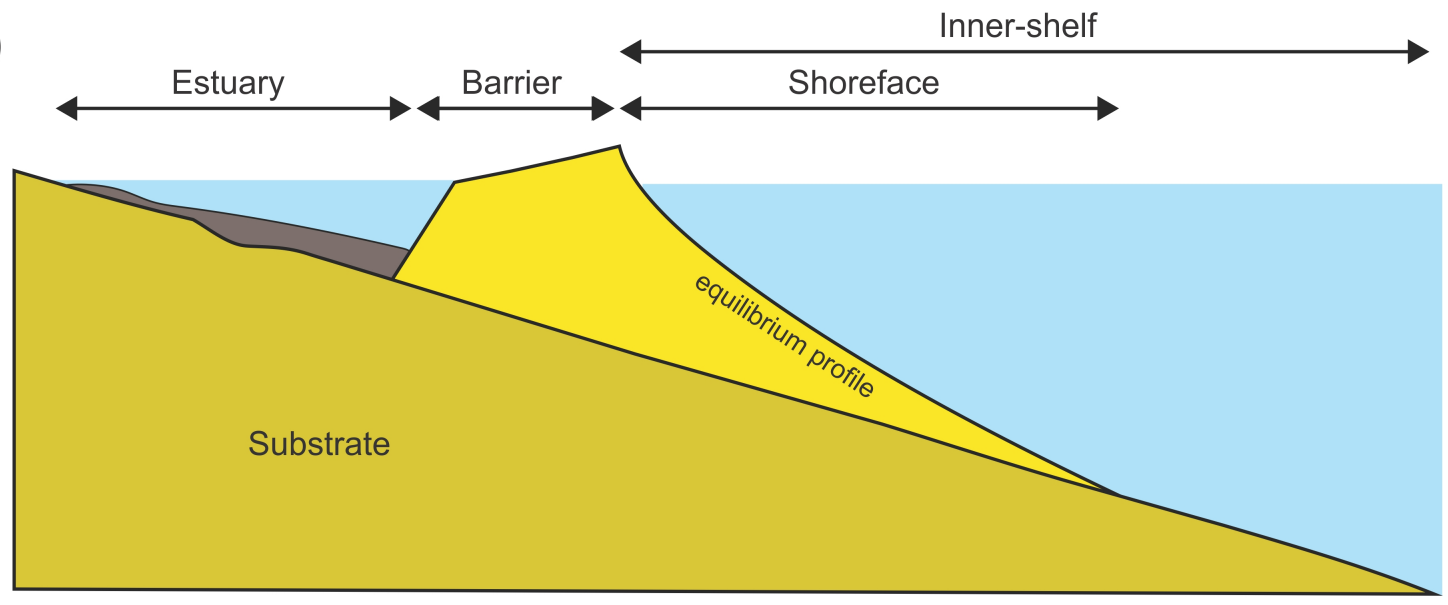

b)

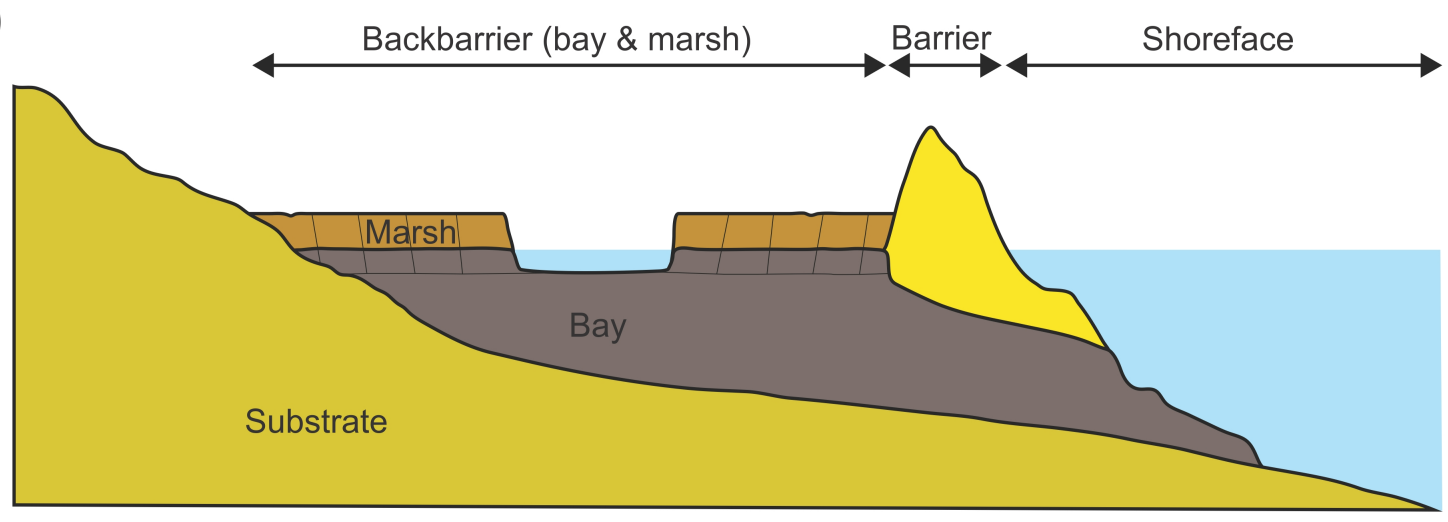

c)
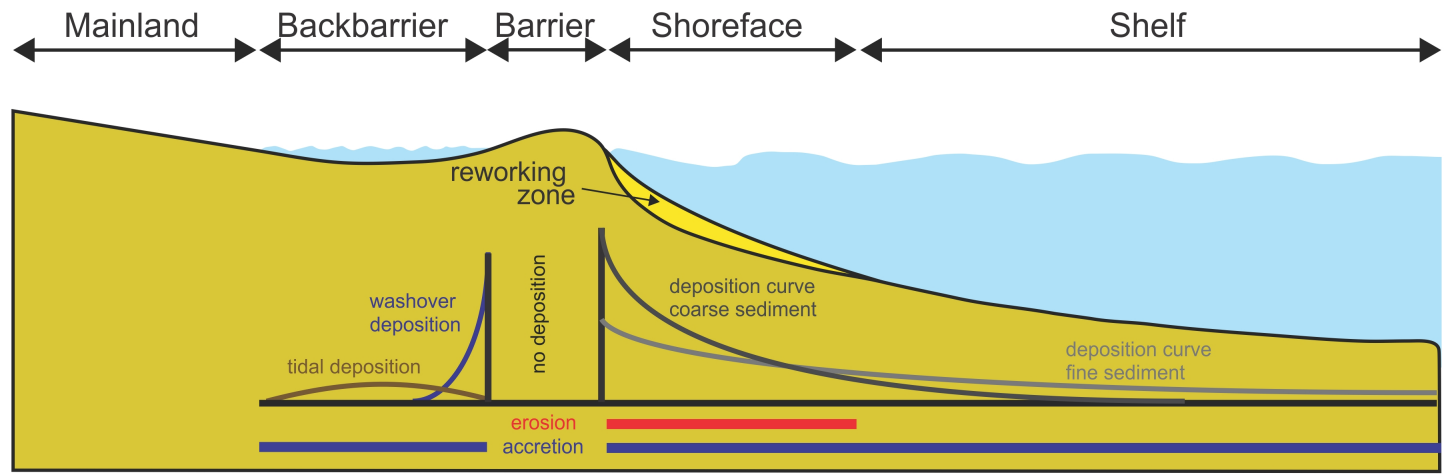


\section{Input \\ Receiving system parameters (Geological inheritance)}

\section{Barrier response}

Mesoscale

dynamic drivers

- storms,

- sea-level,

- cumulative microscale processes

Sediment supply (+ve / -ve)

Size/tidal prism Barrier volume Barrier height Barrier sediment texture Lagoon size (width/depth) Lagoon sedimentation rates Basement slope Basement topography Basement erodibility Drift/swash-aligned Shelf/shoreface morphology
- Rollover

- Overstepping

- Erosion

- Breakdown

- Elongation

- Inlet open/closure

- Aggradation/progradation 


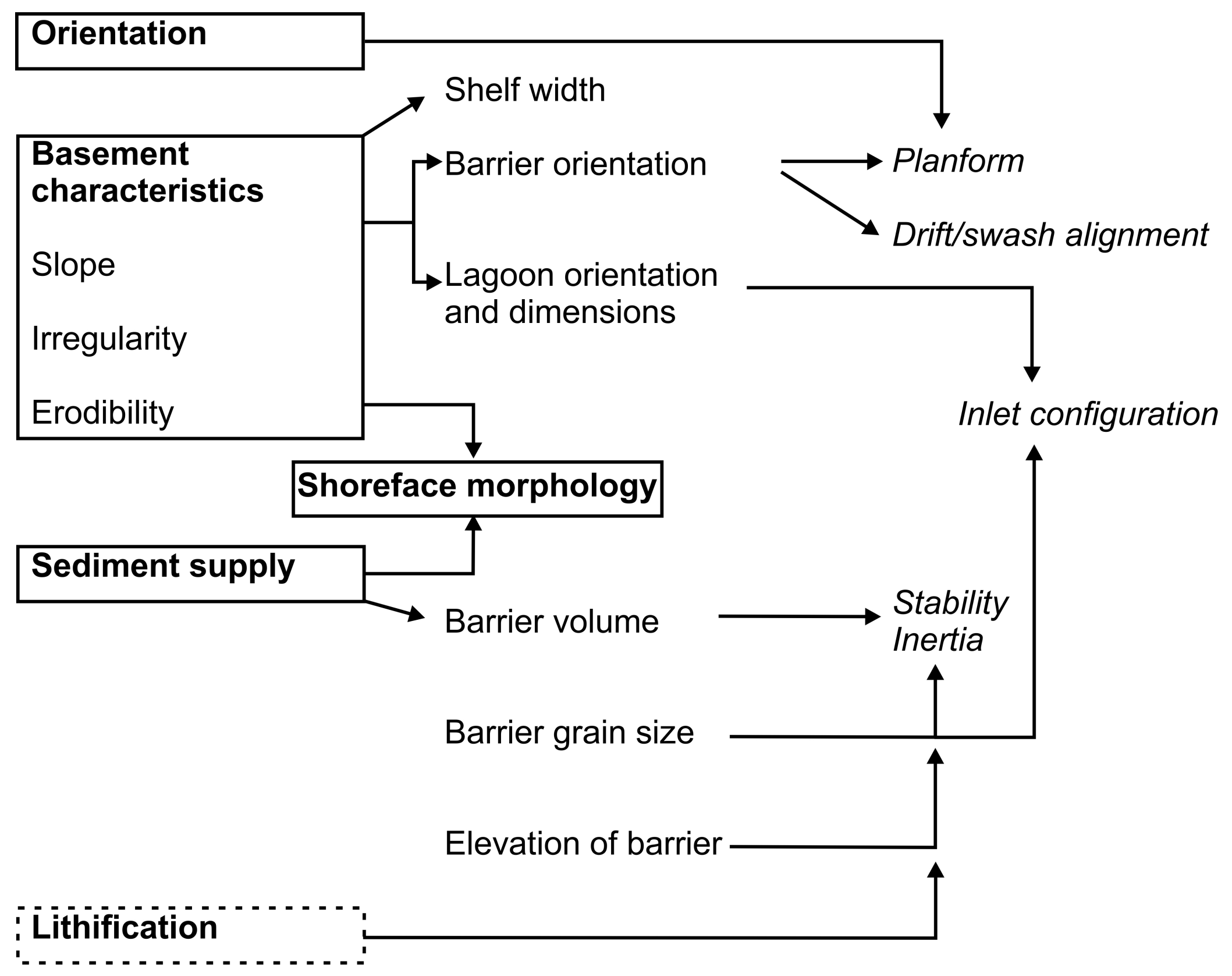




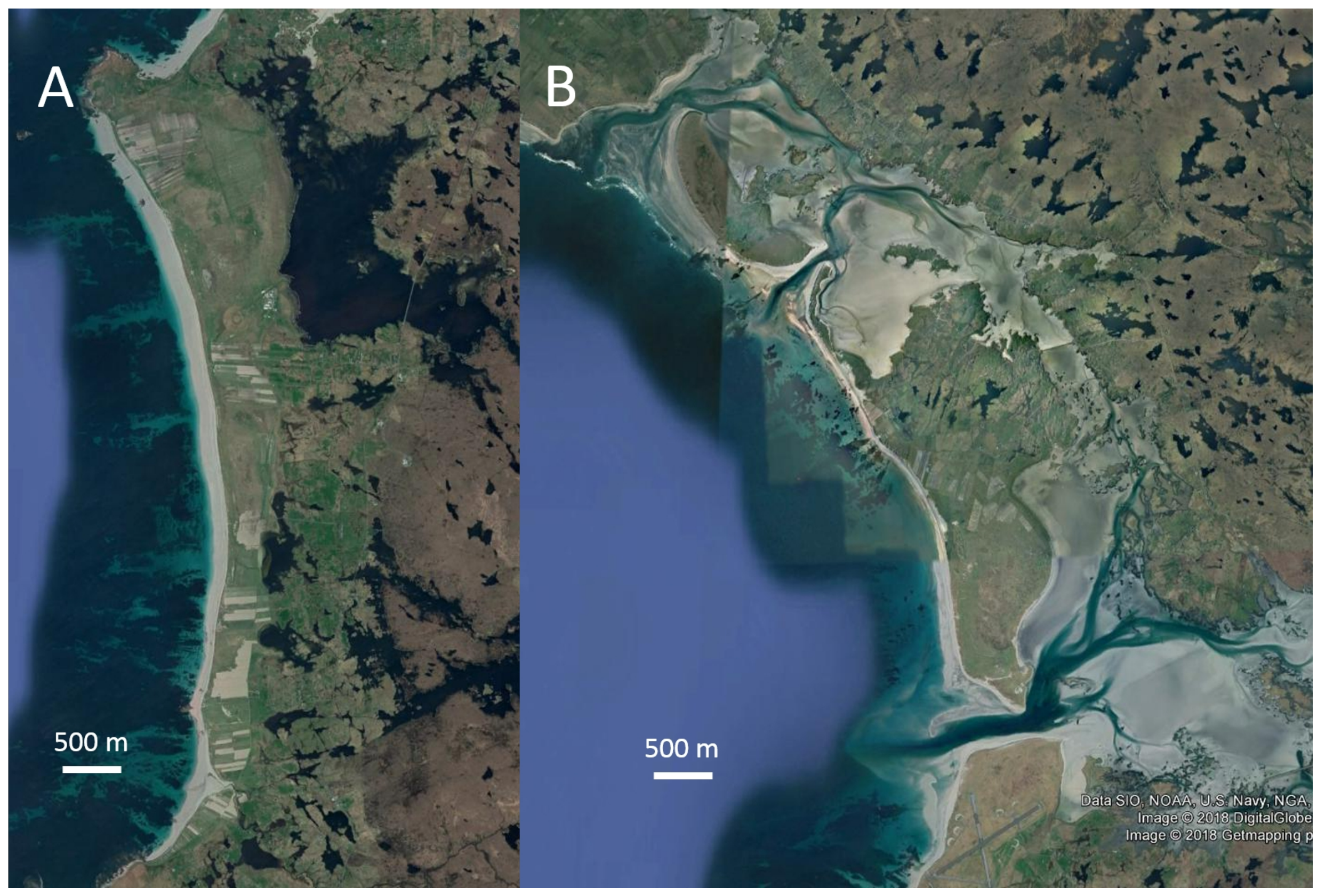

